\title{
ATIQCTPC: a nanomedicine capable of targeting tumor and blocking thrombosis in vivo
}

This article was published in the following Dove Press journal:

International Journal of Nanomedicine

13 June 2017

Number of times this article has been viewed

\author{
Xinyi Xu' \\ Yuji Wang' \\ Jianhui $\mathrm{Wu}^{\prime}$ \\ $\mathrm{Xi} \mathrm{Hu}$ \\ Haimei Zhu' \\ Xiaoyi Zhang' \\ Yaonan Wang' \\ Lin Gui' \\ Ming Zhao',2 \\ Shiqi Peng'
}

'Beijing Area Major Laboratory of Peptide and Small Molecular

Drugs, Engineering Research Center

of Endogenous Prophylactic of

Ministry of Education of China,

Beijing Laboratory of Biomedical

Materials, College of Pharmaceutical

Sciences, Capital Medical University,

Beijing, People's Republic of China;

${ }^{2}$ Department of Biomedical Science

and Environmental Biology, Kaohsiung

Medical University, Kaohsiung, Taiwan, Republic of China

Correspondence: Ming Zhao;

Shiqi Peng

Beijing Area Major Laboratory of

Peptide and Small Molecular Drugs,

Engineering Research Center of

Endogenous Prophylactic of Ministry

of Education of China, Beijing Laboratory

of Biomedical Materials, College of

Pharmaceutical Sciences, Capital Medical

University, Beijing 100069, People's

Republic of China

Tel +86 I0 839I I535;

+86 1083911528

Email mingzhao@bjmu.edu.cn;

sqpeng@bjmu.edu.cn

\begin{abstract}
To overcome the harmful side effects, low tolerance, and undesirable outcomes of the anticancer drugs, we used ethane-1,2-diamine to bridge antitumoral $(S)$-3-acetyl-4-oxotetrahydroindolo[2,3-a]quinolizine-6-carboxylic acid (ATIQC) and tumor-targeting D-glucuronic acid, thereby providing $(6 S)$-3-acetyl-4-oxo- $N$-(2-(3,4,5,6-tetrahydroxytetrahydro-2H-pyran-2carboxamido)ethyl)-4,6,7,12-tetrahydroindolo[2,3-a]quinolizine-6-carboxamide (ATIQCTPC). Atomic force microscopy images visualized, that in serum, ATIQCTPC formed particles of height $<81 \mathrm{~nm}$. These particles effectively avoided phagocytosis of macrophages and were stable in blood circulation. Distribution analysis indicated that ATIQCTPC accumulated and released ATIQC in the tumor tissue through a targeting manner. Thus, the antitumor and the antithrombotic activities of ATIQCTPC were 100-fold higher than those of ATIQC, and ATIQCTPC was able to prevent cancer patients from suffering from thrombosis. Based on the observation that ATIQCTPC decreased serum tumor necrosis factor- $\alpha$ (TNF- $\alpha$ ) and interleukin-8 (IL-8) in S180 mice, we hypothesized that this is the mechanism that ATIQCTPC utilized to slow tumor growth. Additionally, we observed that ATIQCTPC inhibited thrombosis by decreasing serum P-selectin of thrombotic rats. The intermolecular association and the hexamerization manner of ATIQCTPC were experimentally evidenced and correlated with the formation of the nanoparticles.
\end{abstract}

Keywords: tumor, thrombosis, targeting, nanoparticle, TNF- $\alpha$, IL-8, P-selectin

\section{Introduction}

Anticancer drugs that lack tumor selectivity are generally responsible for harmful side effects, low tolerance, and undesirable outcomes. ${ }^{1-3}$ So far, these clinical problems remain unresolved, and a series of efforts have been taken to improve the development of delivery systems of anticancer drugs..$^{4-7}$ Of the developing approaches, the use of a nanomedicine capable of targeting tumor tissue is relevant.

Indoloquinolizines, the natural alkaloid products of indole and the precursors of yohimbanes, belong to $\beta$-carboline family. They can inhibit the synthesis of carcinoma DNA selectively, ${ }^{8}$ downregulate P-selectin expression, ${ }^{9}$ and slow tumor growth. ${ }^{10}$ Indoloquinolizines are also the efficient photosensitizers of cancer cells and thereby are widely used in photodynamic therapy of cancer patients. ${ }^{11,12}$ The diverse pharmacological actions led to the recent stereoselective synthesis of a library of tetrahydroindolo[2,3-a]quinolizines. ${ }^{13}$ Sugar acids, including glucuronic acid, are used ubiquitously in detergent and food industries, as well as in the manufacture of pharmaceutics and cosmetics. ${ }^{14,15}$ The medicinal utility of glucuronic acid includes constructing CT DNA intercalator, ${ }^{16,17}$ constituting a natural heparin-like compound having low anticoagulant activity, ${ }^{18}$ and preparing antitumoral delivery systems for anticancer therapy, in particular. ${ }^{19-25}$ 

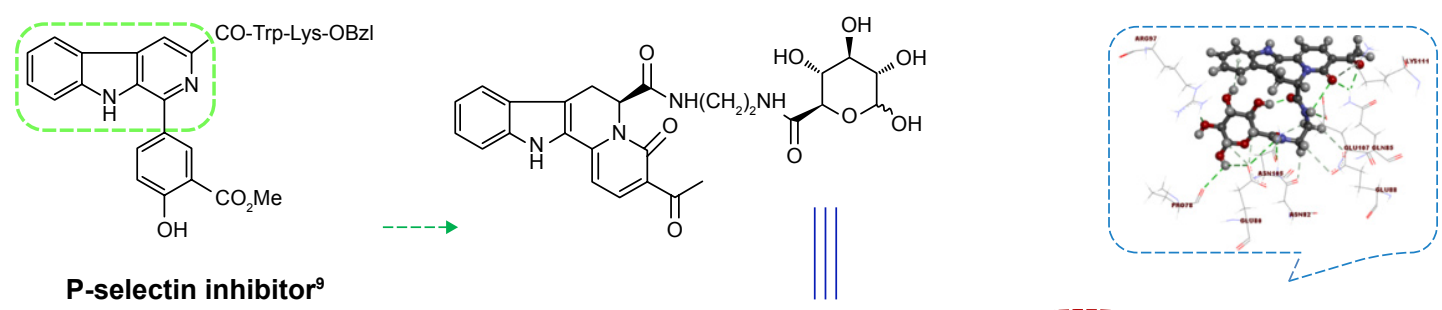

P-selectin inhibitor ${ }^{9}$

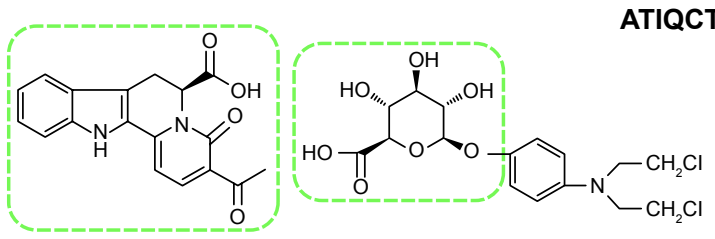

Tumor inhibitor ${ }^{10}$ Tumor targeting pharmacophore ${ }^{21}$
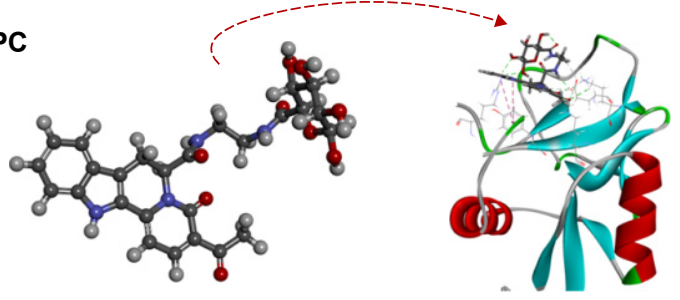

Figure I The combination of P-selectin inhibitor, tumor inhibitor, tumor targeting pharmacophore, and docking toward the active sites of P-selectin leads to designing ATIQCTPC, a nanodelivery system capable of targeting tumor tissue, releasing ATIQC in tumor tissue, slowing tumor growth, depressing P-selectin expression, and inhibiting thrombosis in vivo.

Abbreviations: ATIQC, (S)-3-acetyl-4-oxo-tetrahydroindolo[2,3-a]quinolizine-6-carboxylic acid; ATIQCTPC, (6S)-3-acetyl-4-oxo- $\mathrm{N}$-(2-(3,4,5,6-tetrahydroxytetrahydro2H-pyran-2-carboxamido)ethyl)-4,6,7,I2-tetrahydroindolo[2,3-a]quinolizine-6-carboxamide.

Based on the knowledge of $\beta$-carboline, indoloquinolizine, and glucuronic acid, this study was aimed at the rational design of (6S)-3-acetyl-4-oxo- $N$-(2-(3,4,5,6-tetrahydroxytetrahydro2H-pyran-2-carboxamido)ethyl)-4,6,7,12-tetrahydroindolo[2,3-a]quinolizine-6-carboxamide (ATIQCTPC; Figure 1), a nanodelivery system capable of targeting tumor and blocking thrombosis in vivo. We show that ATIQCTPC is able to downregulate P-selectin expression, decrease the levels of tumor necrosis factor- $\alpha$ (TNF- $\alpha$ ) and interleukin- 8 (IL-8) in serum and tumor tissue, slow tumor growth, and inhibit thrombosis. The thrombosis is one of the fatal complications of cancer patients.

\section{Materials and methods}

\section{General}

Sprague Dawley rats and ICR mice were purchased from the Animal Center of Peking University. Work performed was based on a protocol reviewed and approved by the ethics committee of Capital Medical University. The committee assures that the welfare of the animals is maintained in accordance with the requirements of the Animal Welfare Act. Statistical analyses of all the biological data were carried out using analysis of variance. $P$-values $<0.05$ were considered as statistically significant. The L-amino acids and sodium citrate (analytically pure) were available commercially (SigmaAldrich Corp, St Louis, MO, USA), while acetonitrile was spectroscopically pure and commercially available (Thermo Fisher Scientific, Waltham, MA, USA).

\section{Docking ATIQCTPC into the active pocket of $\mathrm{P}$-selectin ${ }^{26}$}

In the docking investigation, P-selectin's structure was treated as a rigid one and produced with AutoDockTools 1.5, ie, merging the nonpolar hydrogens and assigning the charges of Gasteiger and the elements of AutoDock 4. Then, the energy-minimized conformation of ATIQCTPC was treated as flexible and produced with AutoDockTools 1.5, ie, merging the nonpolar hydrogens, assigning the charges of Gasteiger, finding the root and aromatic carbons, identifying rotatable bonds, and labeling the torsions. Based on the grid spacing of $0.375 \AA$ for two average structures of P-selectin, the dimensions of the grid box were $22.5 \AA \times 30 \AA \times 30 \AA$. AutoDock 4 was used to perform the docking investigation. The conformation of minimal energy of ATIQCTPC was docked into the active pocket of the average structure of P-selectin. This procedure allows the flexible ligand to automatically dock into a rigid receptor containing some flexible residues. For the crystal structure of SLeX, the residues within $4 \AA$ are Tyr45, Ser46, Ser47, Arg85, His108, Lys111, Lys112, and His 114; for the crystal structure of PSGL-1, the residues within $4 \AA$ are Tyr48, Lys84, Arg85, Glu88, Glu92, Tyr94, Ser99, and Glu107; and for $\mathrm{Ca}^{2+}$ coordination, the residues are Glu80, Asn82, Asn105, and Asp106. Only these residues are involved in the active pocket of the average structure. To have the appropriate binding position, orientations, and conformation of ATIQCTPC in the binding site of the average structure, a Lamarckian Genetic Algorithm was used. To start the global optimization, the parameters of a population of 100 randomly positioned individuals were used. The maximum number of energy evaluations and the maximum number of generations in Lamarckian Genetic Algorithm were $2.5 \times 10^{7}$ and $2.7 \times 10^{5}$, respectively. The Solis and Wets local were searched with a maximum number of 3,000 . For each simulation, 256 runs were performed for ATIQCTPC. 
Scoring and clustering produced 256 conformations of ATIQCTPC with the lowest binding energy and a root mean square tolerance of $2.0 \AA$.

\section{Preparation of ATIQCTPC Synthetic route to ATIQCTPC}

Procedures of eight-step reactions

According to Scheme 1, ATIQCTPC was prepared. The route consists of eight-step reactions. The method and the physicochemical data of the individual procedure and the corresponding product are given later in detail.

\section{Preparing benzyl (S)-2-amino-3-(IH-indol-3-yl)} propanoate (I)

Into a mixture of $20.40 \mathrm{~g}$ (100.0 mmol) L-tryptophan (L-Trp) and $13.00 \mathrm{~g}$ (120.0 mmol) of benzyl alcohol, $40.60 \mathrm{~g}$ (120.0 mmol) polyphosphoric acid was added. The reaction mixture was heated at $80^{\circ} \mathrm{C}$ for $72 \mathrm{~h}$ and cooled to room temperature, and then, $30 \mathrm{~mL}$ of anhydrous ether was added into the mixture and stirred for $2 \mathrm{~h}$ to collect $35.40 \mathrm{~g}(90 \%)$ of the title compound as a colorless solid.

\section{Preparing benzyl (3S)-I-(2,2-dimethoxyethyl)-2,3,4,9-} tetrahydro-I H-pyrido[3,4-b]indole-3-carboxylate (2) A solution of $8 \mathrm{~mL}$ of dichloromethane, $123 \mathrm{~mL}(48.8 \mathrm{mmol}$ ) of 1,1,3,3-tetramethoxypropane, and $9 \mathrm{~mL}$ of trifluoroacetic acid was stirred at $0^{\circ} \mathrm{C}$ for $40 \mathrm{~min}$, and then, $10.00 \mathrm{~g}$ (25.5 mmol) of benzyl (S)-2-amino-3-(1H-indol-3-yl) propanoate (1) was added and stirred at room temperature for another $120 \mathrm{~h}$. At $0^{\circ} \mathrm{C}$, saturated aqueous sodium bicarbonate was slowly added into the reaction mixture to adjust to $\mathrm{pH}$ 7. The organic phase was separated, successively washed with $5 \%$ aqueous sodium bicarbonate and saturated aqueous sodium chloride, and dried with anhydrous sodium sulfate. After filtration, the filtrate was evaporated under vacuum and the residue was purified on a silica gel column (petroleum ether/acetone, 3/1) to give $2.21 \mathrm{~g} \mathrm{(22 \% )} \mathrm{of} \mathrm{the}$ title compound as a colorless syrupy. Electrospray ionization mass spectrometry (ESI-MS; $m / e$ ): $395[\mathrm{M}+\mathrm{H}]^{+}$and ${ }^{1} \mathrm{H}$ nuclear magnetic resonance (NMR; $300 \mathrm{MHz}$ DMSO- $d_{6}$ ): $\delta(\mathrm{ppm})=10.83(\mathrm{~d}, J=14.7 \mathrm{~Hz}, 1 \mathrm{H}), 7.43-7.26(\mathrm{~m}, 7 \mathrm{H})$, $7.03(\mathrm{t}, J=7.2 \mathrm{~Hz}, 1 \mathrm{H}), 6.95(\mathrm{t}, J=7.5 \mathrm{~Hz}, 1 \mathrm{H}), 5.23(\mathrm{~s}, 1 \mathrm{H})$, $5.15(\mathrm{~s}, 1 \mathrm{H}), 4.70(\mathrm{~m}, 1 \mathrm{H}), 4.26(\mathrm{~d}, J=10.2 \mathrm{~Hz}, 1 \mathrm{H}), 4.17(\mathrm{~d}$, $J=7.5 \mathrm{~Hz}, 1 \mathrm{H}), 3.97(\mathrm{t}, J=5.7 \mathrm{~Hz}, 1 \mathrm{H}), 3.76(\mathrm{~d}, J=7.5 \mathrm{~Hz}$, 1H), 3.36-3.23 (m, 6H), 3.03-2.65 (m, 2H), 2.42 (m, 1H), $2.13(\mathrm{~m}, 1 \mathrm{H})$, and $1.82(\mathrm{~m}, 1 \mathrm{H})$.

Preparing benzyl (3S)- I-(2,2-dimethoxyethyl)-2-(3oxobutanoyl)-2,3,4,9-tetrahydro- IH-pyrido[3,4-b]indole3-carboxylate (3)

To a solution of $2.93 \mathrm{~g}$ (7.4 mmol) benzyl (3S)-1-(2,2dimethoxyethyl)-2,3,4,9-tetrahydro-1H-pyrido[3,4-b] indole-3-carboxylate (2) in $50 \mathrm{~mL}$ of acetone at $0^{\circ} \mathrm{C}, 0.9 \mathrm{~mL}$ of diketene and $0.6 \mathrm{~mL}$ of triethylamine were added and stirred at room temperature for $17 \mathrm{~h}$. To this reaction mixture, $2.5 \mathrm{~mL}$ of distilled water was added and stirred at $0^{\circ} \mathrm{C}$ for $1 \mathrm{~h}$.<smiles>N[C@@H](Cc1c[nH]c2ccccc12)C(=O)O</smiles><smiles>CC=CC=C[Mg]</smiles><smiles>CCOC(=O)[C@@H]1Cc2c([nH]c3ccccc23)C(COC)(CC(OC)OC)N1</smiles>

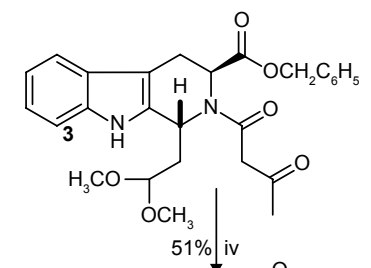

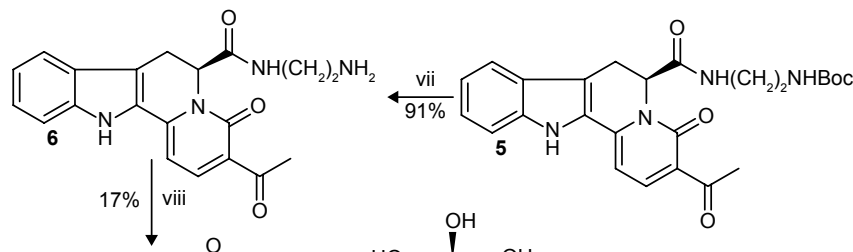

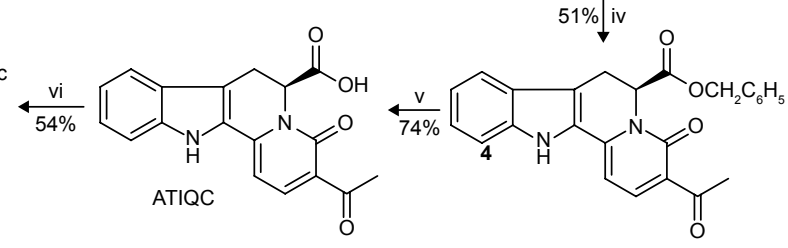<smiles>CC(=O)c1ccc2n(c1=O)[C@@H](C(=O)NCNC(=O)[C@@H]1OC(O)[C@H](O)[C@@H](C)[C@H]1O)Cc1c-2[nH]c2ccccc12</smiles>

Scheme I Synthetic route to ATIQCTPC.

Notes: (i) Polyphosphoric acid and benzyl alcohol, $80^{\circ} \mathrm{C}$. (ii) $\mathrm{CH}_{2} \mathrm{Cl}_{2}, \mathrm{I}, \mathrm{I}, 3,3$-etramethoxypropane and TFA. (iii) $\mathrm{CH}_{3} \mathrm{COCH}_{3}$, diketene, and triethylamine. (iv) $\mathrm{CH}_{3} \mathrm{COCH}_{3}$ and hydrochloric acid $(2 \mathrm{M})$. (v) $\mathrm{MeOH}$ and aqueous $\mathrm{NaOH}(2 \mathrm{M})$. (vi) Boc- $\mathrm{NH}-\left(\mathrm{CH}_{2}\right)_{2}-\mathrm{NH}_{2}$, DCC, HOBt, NMM, and THF. (vii) A solution of hydrogen chloride in ethyl acetate (4 M). (viii) D-Glucuronic acid, DCC, HOBt, NMM, and DMF.

Abbreviations: ATIQCTPC, (6S)-3-acetyl-4-oxo-N-(2-(3,4,5,6-tetrahydroxytetrahydro-2H-pyran-2-carboxamido)ethyl)-4,6,7,12-tetrahydroindolo[2,3-a] quinolizine-6-carboxamide; TFA, trifluoroacetic acid; DCC, dicyclohexylcarbodiimide; HOBt, N-hydroxybenzotriazole; NMM, N-methylmorpholine; THF, tetrahydrofuran; DMF, N,N-dimethylformamide. 
The solution was evaporated under vacuum, and the residue was extracted with dichloromethane three times. The organic phase was successively washed with $5 \%$ aqueous sodium bicarbonate and saturated aqueous sodium chloride and dried with anhydrous sodium sulfate. After filtration, the filtrate was evaporated under vacuum and the residue was purified on a silica gel column (petroleum ether/acetone, 4/1) to give $1.17 \mathrm{~g}$ (33\%) of the title compound as a colorless syrupy solution. ESI-MS (m/e): $479[\mathrm{M}+\mathrm{H}]^{+}$and ${ }^{1} \mathrm{H}$ NMR $(300 \mathrm{MHz}$, DMSO- $\left.d_{6}\right): \delta(\mathrm{ppm})=10.84(\mathrm{~d}, J=3.6 \mathrm{~Hz}, 1 \mathrm{H}), 7.53-7.34$ (m, 3H), 7.33-7.25 (m, 4H), 7.04-7.01 (m, 2H), 5.24-5.19 $(\mathrm{m}, 2 \mathrm{H}), 4.96(\mathrm{~m}, 1 \mathrm{H}), 4.61(\mathrm{~m}, 1 \mathrm{H}), 4.05(\mathrm{~m}, 1 \mathrm{H})$, $3.32-3.23(\mathrm{~m}, 6 \mathrm{H}), 3.15(\mathrm{~s}, 2 \mathrm{H}), 3.00-2.93(\mathrm{~m}, 2 \mathrm{H}), 2.16$ $(\mathrm{d}, J=1.5 \mathrm{~Hz}, 3 \mathrm{H}), 1.97(\mathrm{~m}, 1 \mathrm{H})$, and $1.83(\mathrm{~m}, 1 \mathrm{H})$.

\section{Preparing benzyl (S)-3-acetyl-4-oxo-4,6,7, I2-} tetrahydroindolo[2,3-a]quinolizine-6-carboxylate (4)

With stirring to a solution of $858 \mathrm{mg}(1.8 \mathrm{mmol})$ of benzyl (3S)-1-(2,2-dimethoxyethyl)-2-(3-oxobutanoyl)-2,3,4,9tetrahydro-1H-pyrido[3,4-b]indole-3-carboxylate (3) in $22 \mathrm{~mL}$ of acetone at $0^{\circ} \mathrm{C}, 0.3 \mathrm{~mL}$ of hydrochloric acid (2 M) was added, and the reaction mixture was stirred at room temperature for $24 \mathrm{~h}$, to which aqueous sodium bicarbonate (5\%) was slowly added to adjust to $\mathrm{pH} 7$. The solution was evaporated under vacuum, and the residue was extracted with ethyl acetate three times and successively washed with aqueous sodium bicarbonate (5\%), citric acid (5\%), and saturated aqueous sodium chloride. The organic phase was dried with anhydrous sodium sulfate. After filtration, the filtrate was evaporated under vacuum and the residue was purified on a silica gel column (petroleum ether/acetone, 4/1) to give $377 \mathrm{mg}(51 \%)$ of the title compound as a yellow powder. $\operatorname{ESI-MS}(m / e): 413[\mathrm{M}+\mathrm{H}]^{+} ;{ }^{1} \mathrm{H}$ NMR $\left(300 \mathrm{MHz}, \mathrm{DMSO}-d_{6}\right)$ : $\delta(\mathrm{ppm})=11.99(\mathrm{~s}, 1 \mathrm{H}), 8.21(\mathrm{~d}, J=7.5 \mathrm{~Hz}, 1 \mathrm{H}), 7.23-7.03$ (m, 9H), 6.90 (d, $J=7.8 \mathrm{~Hz}, 1 \mathrm{H}), 6.19$ (d, $J=6.0 \mathrm{~Hz}, 1 \mathrm{H})$, $5.10(\mathrm{~d}, J=4.8 \mathrm{~Hz}, 2 \mathrm{H}), 3.44\left(\mathrm{dd}, J_{1}=7.5 \mathrm{~Hz}, J_{2}=17.4 \mathrm{~Hz}\right.$, $2 \mathrm{H}$ ), and 2.58 (s, 3H); and ${ }^{13} \mathrm{C}-\mathrm{NMR}$ (75 MHz, DMSO- $d_{6}$ ): $\delta(\mathrm{ppm})=196.24,170.05,160.99,143.43,142.90,139.54$, $136.01,132.04,131.61,128.25,127.27,127.19,127.15$, $125.75,125.45,123.85,120.76,120.51,113.71,112.69$, $100.58,67.03,51.11,31.07$, and 22.86.

\section{Preparing (S)-3-acetyl-4-oxo-tetrahydroindolo[2,3-a] quinolizine-6-carboxylic acid (ATIQC)}

With stirring to a solution of $380 \mathrm{mg}(0.9 \mathrm{mmol})$ of benzyl (S)-3-acetyl-4-oxo-4,6,7,12-tetrahydroindolo[2,3-a] quinolizine-6-carboxylate (4) in $15 \mathrm{~mL}$ of methanol at $0^{\circ} \mathrm{C}$, aqueous $\mathrm{NaOH}(2 \mathrm{M})$ was slowly added to adjust to $\mathrm{pH} 12$.
This mixture was stirred at $0^{\circ} \mathrm{C}$ for $96 \mathrm{~h}$, and saturated $\mathrm{KHSO}_{4}$ aqueous solution was slowly added to adjust to $\mathrm{pH}$ 7. The reaction mixture was evaporated under vacuum, and the residue was dissolved in $5 \mathrm{~mL}$ of distilled water, to which saturated aqueous $\mathrm{KHSO}_{4}$ was slowly added at $0^{\circ} \mathrm{C}$ and stirred to adjust to $\mathrm{pH} 3$. The reaction mixture was filtered, and the collected yellow powder was rinsed with distilled water to give $220 \mathrm{mg}$ (74\%) of the title compound as yellow powders. $\mathrm{Mp}: 205^{\circ} \mathrm{C}-207^{\circ} \mathrm{C} ;[\alpha]_{\mathrm{D}}^{25}=-28.3(c=0.10$, $\left.\mathrm{CH}_{3} \mathrm{OH}\right)$; infrared spectroscopy (IR) $\left(\mathrm{KBr}, \mathrm{cm}^{-1}\right): 3,319$, 3,061, 2,291, 2,927, 2,586, 1,743, 1,656, 1,587, 1,546, 1,496, $1,438,1,425,1,363,1,330,1,284,1,236,1,201,1,145,1,111$, 1,029, 972, 852, 781, 746, 624, and 567; ESI-MS (m/e): 321 $[\mathrm{M}-\mathrm{H}]^{-} ;{ }^{1} \mathrm{H}$ NMR $\left(500 \mathrm{MHz}, \mathrm{DMSO}-d_{6}\right): \delta(\mathrm{ppm})=11.92$ (s, 1H), 8.17 (d, $J=8.0 \mathrm{~Hz}, 1 \mathrm{H}), 7.67$ (d, $J=7.5 \mathrm{~Hz}, 1 \mathrm{H})$, 7.44 (d, $J=10.0 \mathrm{~Hz}, 1 \mathrm{H}), 7.28$ (t, $J=6.0 \mathrm{~Hz}, 1 \mathrm{H}), 7.09$ $(\mathrm{t}, J=6.0 \mathrm{~Hz}, 1 \mathrm{H}), 6.85(\mathrm{~d}, J=8.0 \mathrm{~Hz}, 1 \mathrm{H}), 5.96(\mathrm{~d}, J=6.0 \mathrm{~Hz}$, $1 \mathrm{H}), 3.73(\mathrm{~d}, J=16.0 \mathrm{~Hz}, 1 \mathrm{H})$, and $2.55(\mathrm{~s}, 3 \mathrm{H})$; and ${ }^{13} \mathrm{C}-\mathrm{NMR}$ $\left(75 \mathrm{MHz}, \mathrm{DMSO}-d_{6}\right): \delta(\mathrm{ppm})=196.33,171.58,160.99,143.20$, $143.05,139.47,127.26,125.66,125.46,123.73,120.69$, $120.46,113.94,112.68,100.38,52.37,31.11$, and 22.74 .

\section{Preparing Boc-(S)-(2-(3-acetyl-4-oxo-4,6,7, I2-} tetrahydroindolo[2,3-a]-quinolizine-6-carboxamido)ethyl) carbamate (5)

To a solution of $0.5 \mathrm{~mL}$ (4.5 mmol) of $\mathrm{N}$-methylmorpholine, $1.13 \mathrm{~g}(3.5 \mathrm{mmol})$ of ATIQC, $865 \mathrm{mg}(4.2 \mathrm{mmol})$ of dicyclohexylcarbodiimide (DCC), $473 \mathrm{mg}$ (3.5 mmol) of $N$-hydroxybenzotriazole (HOBt), and $16 \mathrm{~mL}$ of anhydrous tetrahydrofuran $(\mathrm{THF})$ at $0^{\circ} \mathrm{C}, 800 \mathrm{mg}(5.0 \mathrm{mmol})$ of Boc$\mathrm{NHCH}_{2} \mathrm{CH}_{2} \mathrm{NH}_{2}$ was added. This mixture was stirred at $0^{\circ} \mathrm{C}$ for $1 \mathrm{~h}$ and at room temperature for $5 \mathrm{~h}$, and thin-layer chromatography indicated the complete disappearance of ATIQC. The reaction mixture was filtered, and the filtrate was evaporated under vacuum. The residue was dissolved in $150 \mathrm{~mL}$ of ethyl acetate, the solution was successively washed with aqueous sodium bicarbonate (5\%) and saturated aqueous sodium chloride, and the ethyl acetate phase was dried with anhydrous sodium sulfate. After filtration and evaporation under vacuum, the residue was purified on a silica gel column $\left(\mathrm{CH}_{2} \mathrm{Cl}_{2} / \mathrm{CH}_{3} \mathrm{OH}, 30 / 1\right)$ to give $879 \mathrm{mg}(54 \%)$ of the title compound as yellow powders. ESI-MS $(m / e): 465$ $[\mathrm{M}+\mathrm{H}]^{+} ;{ }^{1} \mathrm{H}$ NMR $\left(300 \mathrm{MHz}\right.$, DMSO- $\left.d_{6}\right): \delta(\mathrm{ppm})=11.89$ (s, 1H), $8.33(\mathrm{~s}, 1 \mathrm{H}), 8.17$ (d, $J=7.8 \mathrm{~Hz}, 1 \mathrm{H}), 7.61$ (d, $J$ $=8.1 \mathrm{~Hz}, 1 \mathrm{H}), 7.43(\mathrm{~d}, J=8.4 \mathrm{~Hz}, 1 \mathrm{H}), 7.27(\mathrm{t}, J=7.5 \mathrm{~Hz}, 1 \mathrm{H})$, 7.09 (t, $J=7.2 \mathrm{~Hz}, 1 \mathrm{H}), 6.85$ (d, $J=7.5 \mathrm{~Hz}, 1 \mathrm{H}), 5.91$ (d, $J$ $=7.2 \mathrm{~Hz}, 1 \mathrm{H}), 3.66(\mathrm{~s}, 1 \mathrm{H}), 3.09-2.96(\mathrm{~m}, 3 \mathrm{H}), 2.89-2.85(\mathrm{~m}$, $3 \mathrm{H}), 2.56(\mathrm{~s}, 3 \mathrm{H})$, and 1.35 (s, 9H); and ${ }^{13} \mathrm{C}-\mathrm{NMR}(75 \mathrm{MHz}$, 
DMSO- $\left.d_{6}\right): \delta(\mathrm{ppm})=196.34,169.34,161.05,156.02$, $143.88,143.03,139.34,127.53,125.57,125.36,123.50$, $120.48,120.31,113.25,112.59,100.27,78.18,66.09,55.48$, $52.88,31.21,31.15,28.64$, and 23.89 .

Preparing (S)-3-acetyl-N-(2-aminoethyl)-4-oxo-4,6,7, I2tetrahydroindolo-[2,3-a]quinolizine-6-carboxamide (6) The solution of $800 \mathrm{mg}(1.7 \mathrm{mmol})$ of Boc- $(S)-(2-(3-$ acetyl-4-oxo-4,6,7,12-tetra-hydroindolo[2,3-a]quinolizine6-carboxamido)ethyl)carbamate (5) in $6.6 \mathrm{~mL}$ of anhydrous solution of hydrogen chloride in ethyl acetate $(4 \mathrm{M})$ was stirred at $0^{\circ} \mathrm{C}$ for $2 \mathrm{~h}$. The reaction mixture was evaporated under vacuum. The residue was dissolved in ethyl acetate, and the solution was evaporated under vacuum. This procedure was repeated four times to thoroughly remove hydrogen chloride. The residue was triturated with ether to provide $571 \mathrm{mg}(91 \%)$ of the title compound as yellow powders. ESI-MS (m/e): $363[\mathrm{M}-\mathrm{H}]^{-} ;{ }^{1} \mathrm{H}$ NMR $\left(300 \mathrm{MHz}, \mathrm{DMSO}-d_{6}\right): \delta(\mathrm{ppm})=11.94(\mathrm{~s}, 1 \mathrm{H}), 8.59$ (t, $J=5.4 \mathrm{~Hz}, 1 \mathrm{H}), 8.18$ (d, $J=7.8 \mathrm{~Hz}, 1 \mathrm{H}), 7.83(\mathrm{~s}, 3 \mathrm{H})$, $7.62(\mathrm{~d}, J=8.1 \mathrm{~Hz}, 1 \mathrm{H}), 7.44(\mathrm{~d}, J=8.1 \mathrm{~Hz}, 1 \mathrm{H}), 7.28$ (t, $J=7.2 \mathrm{~Hz}, 1 \mathrm{H}), 7.10(\mathrm{t}, J=7.2 \mathrm{~Hz}, 1 \mathrm{H}), 6.88(\mathrm{~d}, J=7.8 \mathrm{~Hz}$, 1H), 5.95 (d, $J=6.9 \mathrm{~Hz}, 1 \mathrm{H}), 3.74(\mathrm{~d}, J=17.4 \mathrm{~Hz}, 1 \mathrm{H})$, $3.24-3.18(\mathrm{~m}, 2 \mathrm{H}), 2.76(\mathrm{t}, J=6.6 \mathrm{~Hz}, 2 \mathrm{H})$, and $2.56(\mathrm{~s}, 3 \mathrm{H})$; and ${ }^{13} \mathrm{C}-\mathrm{NMR}\left(75 \mathrm{MHz}\right.$, DMSO- $\left.d_{6}\right): \delta(\mathrm{ppm})=196.34$, $169.90,161.07,143.74,143.07,139.39,127.50,125.54$, $125.42,123.67,120.53,120.34,113.25,112.63,100.37$, $53.00,38.67,37.31,31.10$, and 23.71 .

Preparing (6S)-3-acetyl-4-oxo-N-(2-(3,4,5,6tetrahydroxytetrahydro-2H-pyran-2-carboxamido)ethyl)4,6,7,12-tetrahydroindolo[2,3-a]quinolizine-6-carboxamide (ATIQCTPC)

To a solution of $0.2 \mathrm{~mL}(1.8 \mathrm{mmol})$ of $N$-methylmorpholine, $182 \mathrm{mg}(0.5 \mathrm{mmol})$ of $(S)$-3-acetyl- $N$-(2-aminoethyl)-4-oxo4,6,7,12-tetrahydroindolo[2,3-a]quinolizine-6-carboxamide (6), $124 \mathrm{mg}(0.6 \mathrm{mmol})$ of DCC, $68 \mathrm{mg}(0.5 \mathrm{mmol})$ of HOBt, $16 \mathrm{~mL}$ of anhydrous $N, N$-dimethylformamide (DMF), and $388 \mathrm{mg}(2.0 \mathrm{mmol})$ of D-glucuronic acid were added at $0^{\circ} \mathrm{C}$ and stirred for $1 \mathrm{~h}$; then the reaction solution was stirred for another $5 \mathrm{~h}$ at room temperature. Thin-layer chromatography indicated the complete disappearance of (6). At $40^{\circ} \mathrm{C}$, the reaction mixture was evaporated under vacuum to remove anhydrous DMF, and the residue was purified by $\mathrm{C} 18$ column chromatography (acetonitrile/ $\mathrm{H}_{2} \mathrm{O}, 2 / 8$ ) to give $46 \mathrm{mg}(17 \%)$ of the title compound as yellow powders. Mp: $171^{\circ} \mathrm{C}-172^{\circ} \mathrm{C} ;[\alpha]_{\mathrm{D}}{ }^{25}=8.4\left(c=0.10, \mathrm{H}_{2} \mathrm{O}\right)$; IR $\left(\mathrm{KBr}, \mathrm{cm}^{-1}\right)$ : $3,410,3,251,1,643,1,637,1,614,1,587,1,552,1,504,1,384$,
$1,361,1,332,1,284,1,263,1,246$, and 1,114; high-resolution mass (HRMS)-ESI(-) calculated for $\mathrm{C}_{26} \mathrm{H}_{27} \mathrm{~N}_{4} \mathrm{O}_{9}: 539.1784$, found: $539.1777 ;{ }^{1} \mathrm{H}$ NMR (800 MHz, DMSO- $\left.d_{6}\right): \delta$ (ppm) $=11.87(\mathrm{~s}, 1 \mathrm{H}), 8.32(\mathrm{~m}, 1 \mathrm{H}), 8.17(\mathrm{~d}, J=8.0 \mathrm{~Hz}, 1 \mathrm{H}), 7.94$ (m, 1H), $7.63(\mathrm{t}, J=6.4 \mathrm{~Hz}, 1 \mathrm{H}), 7.43(\mathrm{~d}, J=8.0 \mathrm{~Hz}, 1 \mathrm{H})$, 7.28 (t, $J=8.0 \mathrm{~Hz}, 1 \mathrm{H}), 7.10$ (t, $J=8.0 \mathrm{~Hz}, 1 \mathrm{H}), 6.85$ (d, $J$ $=7.2 \mathrm{~Hz}, 2 \mathrm{H}), 6.50(\mathrm{~s}, 1 \mathrm{H}), 5.91(\mathrm{~d}, J=7.2 \mathrm{~Hz}, 1 \mathrm{H}), 5.03(\mathrm{~s}$, 1H), $4.95(\mathrm{~m}, 1 \mathrm{H}), 4.80(\mathrm{~s}, 1 \mathrm{H}), 4.60(\mathrm{~s}, 1 \mathrm{H}), 4.30(\mathrm{~m}, 1 \mathrm{H})$, $3.63(\mathrm{~m}, J=16.8 \mathrm{~Hz}, 1 \mathrm{H}), 3.48(\mathrm{~m}, 1 \mathrm{H}), 3.40(\mathrm{~m}, 1 \mathrm{H}), 3.32$ $(\mathrm{m}, 1 \mathrm{H}), 3.17(\mathrm{~m}, 1 \mathrm{H}), 3.08-2.95(\mathrm{~m}, 5 \mathrm{H}), 2.56(\mathrm{~s}, 3 \mathrm{H})$; and ${ }^{13} \mathrm{C}-\mathrm{NMR}\left(200 \mathrm{MHz}, \mathrm{DMSO}-d_{6}\right): \delta(\mathrm{ppm})=196.37,170.67$, $169.77,169.73,169.28,161.05,143.85,143.03,139.36$, $127.54,125.59,125.38,123.59,120.55,120.40,120.35$, 119.94, 113.29, 113.28, 112.59, 100.28, 97.76, 93.22, 76.74, 75.84, 74.88, 73.11, 72.75, 72.33, 72.13, 52.91, 39.15, 38.34, 31.17 , and 23.89 .

\section{Determining the molecular association of ATIQCTPC}

The molecular association and the resulting polymer of ATIQCTPC were determined with FT-MS spectra, rotatingframe Overhauser effect spectroscopy (ROESY) $2 \mathrm{D}^{1} \mathrm{H}$ NMR spectra, and 3D structure generation. The methods are given later in detail.

\section{Determining the FT-MS spectra of aqueous ATIQCTPC}

FT-MS spectra of a solution of ATIQCTPC in ultrapure water $\left(10^{-9} \mathrm{M}, \mathrm{pH} 7.0\right)$ were acquired using a Solarix FT-ion cyclotron resonance-MS (Bruker Corporation, Billerica, MA, USA) consisting of an ESI/matrix-assisted laser desorption/ ionization (MALDI) dual ion source and a $9.4 \mathrm{~T}$ superconductive magnet. Measurements were carried out with both positive and negative MALDI ion modes. A Smartbeam-II laser (wavelength: $355 \mathrm{~nm}$, focus setting: "medium", repetition rate: $1,000 \mathrm{~Hz}$ ) was used as the ion source. The collisioninduced dissociation (qCID) mass was set to $2,000 \mathrm{~m} / \mathrm{z}$, and the isolation window was $5 \mathrm{~m} / \mathrm{z}$. Data were acquired using solariXcontrol software. Spectral data were processed with data analysis software (Bruker Corporation).

\section{Recording ROESY 2D 'H NMR spectra of ATIQCTPC}

${ }^{1} \mathrm{H}$ NMR experiments of ATIQCTPC were performed on Bruker Avance III $800 \mathrm{MHz}$ spectrometer operating at $18.8 \mathrm{~T}$ equipped with a CPQCI cryoprobe of $5 \mathrm{~mm}$; the signals were observed at $800.25 \mathrm{MHz}$ and recorded at $303 \mathrm{~K}$. DMSO- $d_{6}$ and tetramethylsilane were used as the solvent and the 
internal standard, respectively. The spectrum was acquired using spectral width of $16,447 \mathrm{~Hz}$, data points of 65,536 , pulse width of $8.78 \mu \mathrm{s}$, relaxation delay of $1.0 \mathrm{~s}$, acquisition time of $2 \mathrm{~s}$, and 16 scans. To enhance the sensitivity before Fourier transforms, the spectrum was processed, accurately phased, and baseline adjusted by applying an exponential line broadening of $0.3 \mathrm{~Hz}$. ROESY $2 \mathrm{D}{ }^{1} \mathrm{H}$ NMR spectrum was recorded by a phase-sensitive mode with 2,048 points and 512 points in the $\mathrm{F} 2$ and the $\mathrm{F} 1$ directions, respectively. NOESY 2D ${ }^{1} \mathrm{H}$ NMR spectrum was acquired with 12 scans, relaxation delay of $2 \mathrm{~s}$, and mixing time values of $0.30 \mathrm{~s}$.

\section{Generation of 3D structure and hexamer of ATIQCTPC}

By using ChemDraw Ultra 10.0 (CambridgeSoft, MA, USA), the 2D and 3D structures of ATIQCTPC were sketched. The 3D structure was produced and energy minimized until the minimum root-mean-square (RMS) reached 0.001; then, with the Merck molecular force field, the energy was further minimized using Discovery Studio 2.1 (with a Merck molecular force field; Merck \& Co., NY, USA). For generating conformation, the energy-minimized conformation of ATIQCTPC was used as the starting point. Via systematic search of Discovery Studio 2.1, the energy-minimized conformations were sampled from the whole conformational space. With the Smart minimizer and using the Chemistry at Harvard Macromolecular Mechanics (CHARMM) force field, systematic search and BEST methods were performed. At $300 \mathrm{~K}$, the maximum minimization steps were 200, the gradient of minimization RMS was $0.1 \AA$, and the energy threshold was $20 \mathrm{kcal} / \mathrm{mol}$. From the maximum generated 255 conformations with $0.2 \AA$ of RMS deviation (RMSD), the energy-minimized one was used to construct the hexamer. In brief, the energy-minimized conformation was used as a structure unit and in total six energy-minimized conformations were manually approached based on six cross-peaks of ROESY 2D NMR of ATIQCTPC, so that the distances between two protons involved in each cross-peak could be $<4.0 \AA$. The distances between the protons involved in cross-peaks 1-6 are shown in Figure 3.

\section{Measure and prediction of the nanofeatures of ATIQCTPC}

To explore the nanofeature of ATIQCTPC in solution and in solid state, the transmission electron microscopy (TEM) image of aqueous ATIQCTPC and the scanning electron microscopy (SEM) image of lyophilized powders of ATIQCTPC were recorded. To explore the nanofeature of ATIQCTPC in blood circulation the atomic force microscopy
(AFM) image of ATIQCTPC in rat plasma was recorded. To theoretically predict the nanofeature of ATIQCTPC, the mesoscale simulation was performed.

\section{TEM images of ATIQCTPC in water}

The aqueous ATIQCTPC $\left(10^{-7} \mathrm{M}, \mathrm{pH} 7.0\right)$ was dripped onto a formvar-coated copper grid and examined with a TEM (JSM-6360 LV; JEOL, Tokyo, Japan). After thorough drying in air, the copper grid was kept at $35^{\circ} \mathrm{C}$ for $24 \mathrm{~h}$. To determine the feature and diameter distributions, the copper grid was viewed under TEM by counting $>100$ species in the regions selected randomly. Each determination was performed with triplicate copper grids. TEM images were recorded at an electron beam accelerating voltage of $80 \mathrm{kV}$ and on a 6,000-400,000 $\times$ digitally enlarged imaging plate (Gatan Bioscan Camera Model 1792; Gatan, Inc., Pleasanton, CA, USA) with $20 \mathrm{eV}$ energy windows.

\section{SEM images of lyophilized powders of ATIQCTPC}

To examine the particle size of ATIQCTPC, we also used SEM (50 kV; JEM-1230; JEOL). Lyophilized powders formed from aqueous ATIQCTPC $\left(10^{-7} \mathrm{M}, \mathrm{pH} 7\right)$ were attached onto a copper plate with double-sided tape (Euromedex, Souffelweyersheim, France). On a JEOL JFC1600 Auto Fine Coater, the specimens were coated with $20 \mathrm{~nm}$ gold-palladium. At $15 \mathrm{kV}, 30 \mathrm{~mA}$, and $200 \mathrm{mTorr}$ (argon), the coater was operated for $60 \mathrm{~s}$. The nanofeature and size distribution of the particles were visualized by examining $>100$ particles in randomly selected regions of the SEM alloy. Each measurement was performed with triplicate copper plates. The images were recorded on a 100-10,000× digitally enlarged imaging plate of Gatan Bioscan Camera Model 1792 with 20 eV energy windows.

\section{AFM images of ATIQCTPC in rat plasma}

Into a syringe containing $0.5 \mathrm{~mL}$ of anticoagulant sodium citrate $(3.8 \%) 4.5 \mathrm{~mL}$ of blood of a Wistar rat (male, 250-300 g, 8 weeks old) was collected. The blood was centrifuged at $200 \times g$ for $20 \mathrm{~min}$ to get the plasma. Into this plasma, the solution of ATIQCTPC in normal saline (NS) was added to prepare a solution of ATIQCTPC in rat plasma (final concentration, $10^{-7} \mathrm{M}$ ). This solution was sampled, and its AFM images were recorded on a Nanoscope 3D AFM (Veeco Instruments, Inc., Plainview, NY, USA) in ambient conditions using the contact mode.

\section{Mesoscale simulation of nanoparticle of ATIQCTPC}

The structure of ATIQCTPC was sketched using ChemDraw Ultra 10.0, which was transformed into $3 \mathrm{D}$ conformation 
using Materials Studio 3.2 (Accelrys, Inc., USA) and entirely optimized with MS Forcite module (BIOVIA, San Diego, CA, USA). The geometry of the prepared model of ATIQCTPC was first optimized until the maximum energy convergence and the maximum force changed to $2 \times 10^{-5} \mathrm{kcal} / \mathrm{mol}$ and $0.001 \mathrm{kcal} / \mathrm{mol} / \AA$, respectively. The molecular dynamic simulation was performed at $500 \mathrm{~K}$ using NVT ensemble till equilibration. The final structure of ATIQCTPC was further optimized with MS Dmol ${ }^{3}$ module, based on which a rigid coarse grain model of three connected spherical beads was built. In a cubic box of $200 \times 200 \times 200 \AA^{3}$, three-spherical-bead model was randomly distributed with a density of $0.15 \mathrm{~g} / \mathrm{cm}^{3}$, and a simulation of $15,000 \mathrm{ps}$ was performed at $298 \mathrm{~K}$ using NVT ensemble.

\section{Measuring particle size and zeta potential of ATIQCTPC in water}

The particle size and surface zeta potential of the particles of ATIQCTPC in ultrapure water of $\mathrm{pH} 2.0$ and in phosphatebuffered saline (PBS) of $\mathrm{pH} 7.4$ were measured using a Particle Size Analyzer (ZetaPlus S/N 21394; Brookhaven Instruments Corporation, Holtsville, NY, USA) by using a dynamic light scattering (DLS) model. The size measurement was repeated for three runs per sample. The surface zeta potential of the particles of ATIQCTPC in ultrapure water of $\mathrm{pH} 2.0$ and in PBS of $\mathrm{pH} 7.4$ was measured using a ZetaPlus Potential Analyzer (ZetaPlus S/N 21394) with a BIC Zeta Potential Analyzer. The concentration of the solution of ATIQCTPC in ultrapure water of $\mathrm{pH} 2.0$ and in $\mathrm{PBS}$ of $\mathrm{pH} 7.4$ was $10^{-6} \mathrm{M}$, and the testing temperature was $25^{\circ} \mathrm{C}$. The zeta potential measurement was repeated for three runs per sample, and the data were calculated automatically using the software from the electrophoretic mobility based on Smoluchowski's formula.

\section{Bioassays of ATIQCTPC}

Antitumor assay of ATIQCTPC in vivo

One of the bioassays of ATIQCTPC is the antitumor assay. Usually, a drug is administrated to animals for 7 consecutive days. To sufficiently examine the toxicity of ATIQCTPC, the administration of 7 consecutive days is used here. On S180 mouse model, the antitumor activity of ATIQCTPC in vivo was evaluated. In brief, at $21^{\circ} \mathrm{C}$ in a conventional animal colony, the ICR mice (male, commercially provided by Capital Medical University) were maintained with a natural day/night cycle. At the beginning of the experiment, the mice were 10 weeks old. The mice were subcutaneously injected with S180 ascites tumor cells to form solid tumors. To form subcutaneous tumors, S180 ascites tumor cells were obtained from tumor-bearing mice and serially transplanted once per week. To implant subcutaneous tumors, $0.2 \mathrm{~mL}$ of NS containing $2 \times 10^{6}$ viable tumor cells was injected under the skin at the right armpit. After $24 \mathrm{~h}$ of implantation, the mice were randomly divided into five groups (12 mice/group), ie, ATIQCTPC (oral administration: 0.001, 0.01, and $1 \mu \mathrm{mol} / \mathrm{kg} / \mathrm{day}$ ), doxorubicin (intraperitoneal administration: $2 \mu \mathrm{mol} / \mathrm{kg} /$ day, positive control), NS (oral administration, vehicle control), and sham groups (without administration). The mice were administered with a solution of ATIQCTPC in NS or a solution of doxorubicin in NS or NS alone for 7 days and weighed daily, or the mice were administered nothing and weighed daily. After $24 \mathrm{~h}$ of the last treatment, mice were weighed, received ether anesthesia, sacrificed, and dissected to weigh the tumor immediately.

\section{In vivo anti-thrombotic assay of ATIQCTPC 27,28} Another one of the bioassays of ATIQCTPC is the antithrombotic assay. Wistar rats (male, 250-300 g, 8 weeks old) were used in this assay. Aspirin, ATIQC, and ATIQCTPC were dissolved in NS just before the administration. Rats were orally dosed with ATIQC ( $1 \mu \mathrm{mol} / \mathrm{kg}$, reference control), ATIQCTPC $(0.01 \mu \mathrm{mol} / \mathrm{kg})$, aspirin $(167 \mu \mathrm{mol} / \mathrm{kg}$, positive control), or $\mathrm{NS}(10 \mathrm{~mL} / \mathrm{kg}$, vehicle control). After $30 \mathrm{~min}$ of oral administration, rats received anesthesia of intraperitoneal pentobarbital sodium $(80.0 \mathrm{mg} / \mathrm{kg}$; Beijing Pharmaceutical Works, Beijing, People's Republic of China). The right carotid artery and left jugular vein of the rats were separated. A $6 \mathrm{~cm}$ thread was weighed and then inserted into the middle of a polyethylene tube that was filled with heparin sodium (50 IU/mL, in NS). Into the left jugular vein, one end of the polyethylene tube was inserted. Through the other end of the polyethylene tube, an anticoagulant, heparin sodium, was injected, and this end was inserted into the right carotid artery. Blood flowed from the right carotid artery to the left jugular vein for 15 min through the polyethylene tube. The thread was retrieved to weigh the thrombus, and the rats under anesthesia of pentobarbital sodium were euthanized immediately by exsanguination from the right carotid artery.

\section{Addressing the effect of ATIQCTPC on P-selectin expression}

\section{Addressing the effect of ATIQCTPC on P-selectin expression in vitro}

Enzyme immunoassay (Rat P-selectin ELISA kit; CUSABIO Co., MD, USA) was used to measure P-selectin expression of activated platelets from citrated rat blood. In brief, $980 \mu \mathrm{L}$ of platelet-rich plasma was prepared by centrifuging rat blood at $1,000 \mathrm{rpm}$ for $15 \mathrm{~min}$. To this plasma, $10 \mu \mathrm{L}$ solution of 
arachidonic acid (AA) in NS $(0.15 \mathrm{mg} / \mathrm{mL})$ and $10 \mu \mathrm{L}$ of NS or $10 \mu \mathrm{L}$ solution of ATIQCTPC in NS (final concentration, $1 \mu \mathrm{M}$ ) were added and incubated at $37^{\circ} \mathrm{C}$ for 3 min to prepare the blank or test samples. Into control wells or test wells of a 96 -well plate coated with the enzyme, $100 \mu \mathrm{L}$ of blank sample or test sample was added. The 96-well plate was incubated at $37^{\circ} \mathrm{C}$ for $120 \mathrm{~min}$. After removing the solvent, $100 \mu \mathrm{L}$ of biotin labeling antibody (from the kit) was added to each well. The plate was incubated at $37^{\circ} \mathrm{C}$ for $60 \mathrm{~min}$. After removing the solvent, the wells were washed with washing solution (from the kit) three times. To each well, $100 \mu \mathrm{L}$ of horseradish peroxidase labeling avidin (from the kit) was added, and the plate was incubated at $37^{\circ} \mathrm{C}$ for another $60 \mathrm{~min}$. Upon removal of the solvent, the wells were washed with washing solution (from the kit) five times. To the well, $90 \mu \mathrm{L}$ of the substrate (from the kit) was added. The plate was incubated at $37^{\circ} \mathrm{C}$ in the dark for $20 \mathrm{~min}$ for coloration. Next, the well was treated with $50 \mu \mathrm{L}$ of stop solution (from the kit) for $15 \mathrm{~min}$ to stop the coloration. At $450 \mathrm{~nm}$, the optical density (OD) value of the well was measured, and P-selectin concentration was calculated from the standard curve (from the kit).

\section{Addressing the effect of ATIQCTPC on P-selectin expression of $\mathrm{SI} 80$ mice}

Into a syringe containing $0.5 \mathrm{~mL}$ of anticoagulant sodium citrate (3.8\%), $1 \mathrm{~mL}$ of blood was collected from the $\mathrm{S} 180$ mice orally receiving NS or ATIQCTPC $(1,0.01$, and $0.001 \mu \mathrm{mol} / \mathrm{kg} / \mathrm{day}$ ) in the antitumor assay and centrifuged at $200 \times g$ for $20 \mathrm{~min}$ to get $960 \mu \mathrm{L}$ of serum, which was incubated at $37^{\circ} \mathrm{C}$ for $10 \mathrm{~min}$, and $20 \mu \mathrm{L}$ solution of AA in NS $(0.15 \mathrm{~g} / \mathrm{L})$ was added to incubate for another $5 \mathrm{~min}$. The plate was treated by following the instructions of the manufacturer (Rat P-selectin ELISA Kit; Wuhan Huamei Biotech Co., Ltd., Wuhan, Hubei Province, People's Republic of China). The OD value of each well was measured at $450 \mathrm{~nm}$, and the concentration of P-selectin was calculated based on the standard samples from the kit. Similarly, ATIQCTPC downregulating the serum P-selectin of the treated rats encourages us to hypothesize that via decreasing serum P-selectin, ATIQCTPC inhibits the rats to form thrombi.

\section{Examining the accumulation of ATIQCTPC in tumor tissue}

To estimate the specific distribution of ATIQCTPC in the tumor tissue, the kidney, the heart, the brain, and the liver of the treated S180 mice, the FT-MS tests for their extracts were performed. In brief, tumor tissue and the organs of six S180 mice treated with NS and $1 \mu \mathrm{mol} / \mathrm{kg} /$ day of ATIQCTPC were quantitatively collected and homogenized. The individual homogenate was extracted with chromatographic pure methanol thoroughly. The methanol extract was evaporated under vacuum, the residue was dissolved in $1 \mathrm{~mL}$ of chromatographic pure methanol, and the methanol solution was centrifuged at $10,000 \times g$ for $10 \mathrm{~min}$. The volume of the supernatant was accurately determined, from which $10 \mu \mathrm{L}$ of the solution was injected to record the FT-MS spectrum.

\section{Results \\ Procedure of an eight-step synthetic scheme is suitable for preparing ATIQCTPC}

Using an eight-step synthetic scheme, ATIQCTPC was synthesized. The yields of eight-step reactions are shown in Scheme 1, and most of the yields are acceptable. On a system of Agilent Technologies 1200 Series (Santa Clara, CA, USA) with aqueous acetonitrile as a mobile phase, a highperformance liquid chromatography (HPLC) analysis was performed. The chromatogram showed that the HPLC purity of ATIQCTPC from the eight-step reactions was $98.9 \%$.

\section{In water,ATIQCTPC forms hexamer}

The FT-MS spectrum of aqueous ATIQCTPC was recorded to examine its molecular association. Figure $2 \mathrm{~A}$ shows a divalent ion peak at 1,621.56959, the mass of hexamer plus $\mathrm{H}$ (inset b), a divalent ion peak at 1,351.47649, the mass of pentamer plus H (inset a), an ion peak at 1,621.56959, the mass of trimer plus $\mathrm{H}$ (also refer inset b), an ion peak at 1,081.38120, the mass of dimer plus $\mathrm{H}$ and an ion peak at 541.19245, the mass of monomer plus $\mathrm{H}$. The qCID spectra of the hexamer, the pentamer, and the dimer show that in FT-MS/MS condition, the monomer, dimer, trimer, and pentamer result from the fragmentation of the hexamer. Figure 2 also indicates that the FT-MS spectrum and the qCID spectra do not give the ion peak of the tetramer.

\section{Hexamerization manner of ATIQCTPC}

The hexamerization manner of ATIQCTPC was revealed with ROESY $2 \mathrm{D}^{1} \mathrm{H}$ NMR. Figure $3 \mathrm{~A}$ shows six key crosspeaks denoted with red circles. Cross-peak 1 mirrors the interaction between the $\mathrm{C}_{3}$ of the quinolizine moiety of one molecule and the $\mathrm{CH}$ of the quinolizine moiety of another molecule, cross-peak 2 mirrors the interaction between the $\mathrm{H}$ at 5-position of indole moiety of one molecule and the $\mathrm{H}$ at 1-position of pyran moiety of another molecule, crosspeak 3 mirrors the interaction between the $\mathrm{H}$ at 7-position of indole moiety of one molecule and the $\mathrm{H}$ of quinolizine amide of another molecule, cross-peak 4 mirrors the 


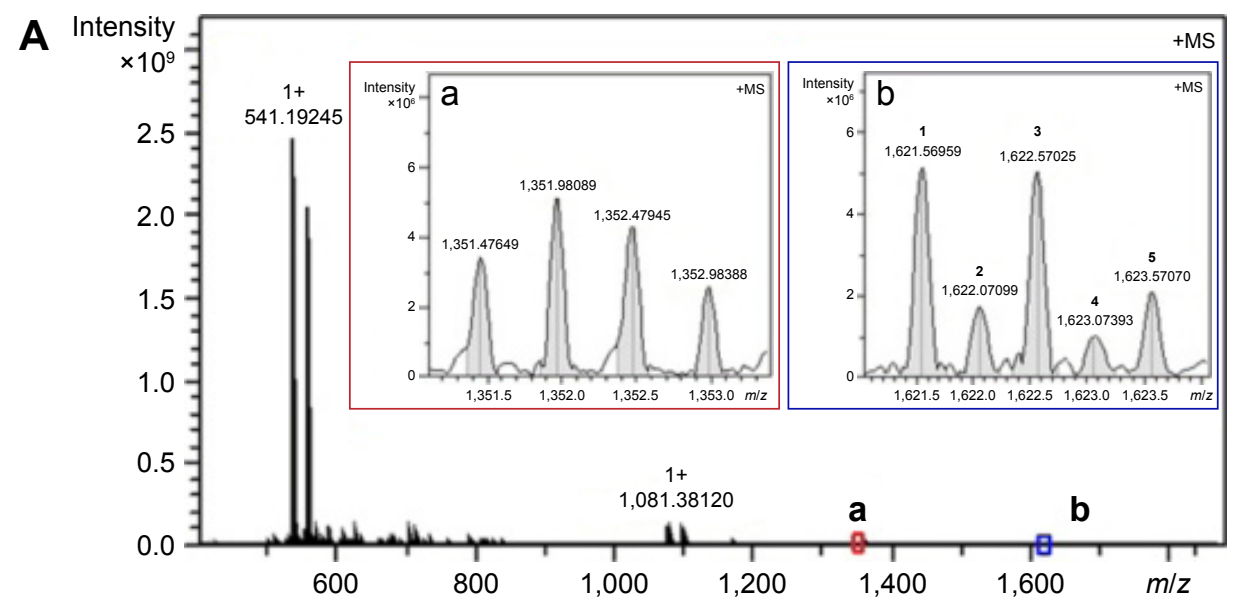

B

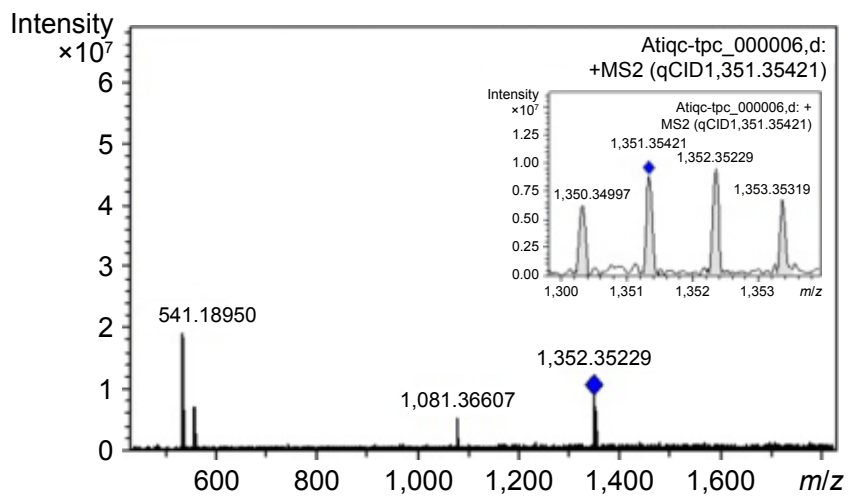

C

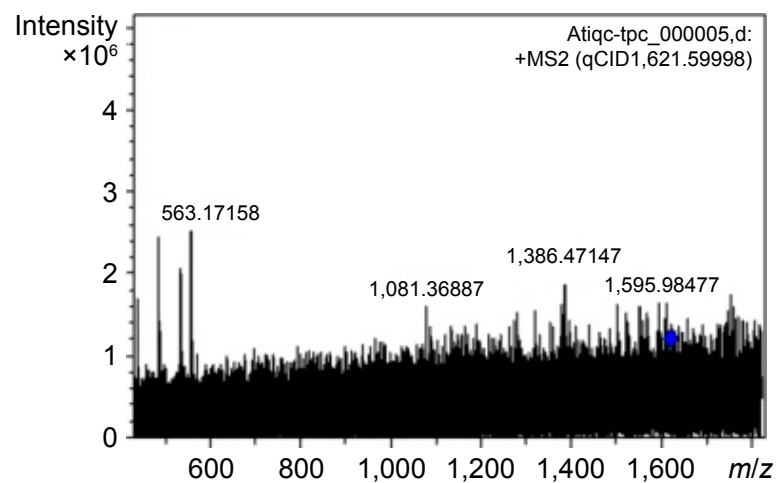

Figure 2 FT-MS and qCID spectra of ATIQCTPC.

Notes: (A) FT-MS spectrum of ATIQCTPC, in which the divalent ion peak of the hexamer (b), the divalent ion peak of the pentamer (a), and the ion peak of the trimer are amplified and inserted. (B) qCID spectrum of the pentamer, in which the ion peaks of the monomer and the dimer are amplified and inserted. (C) qCID spectrum of the trimer, in which the ion peaks of the monomer and the dimer are amplified and inserted.

Abbreviations:MS, massspectrometry; qCID, collision-induceddissociation;ATIQCTPC,(6S)-3-acetyl-4-oxo-N-(2-(3,4,5,6-tetrahydroxytetrahydro-2H-pyran-2-carboxamido) ethyl)-4,6,7,I2-tetrahydroindolo[2,3-a]quinolizine-6-carboxamide.

interaction between the $\mathrm{H}$ of pyran amide of one molecule and the $\mathrm{H}$ at 3-position of pyran moiety of another molecule, and cross-peaks 5 and 6 mirror the interactions between the $\mathrm{H}$ at pyrrole moiety of one molecule and the $\mathrm{OH}$ at 1-, 2-, 3 - and 4-position of the pyran moiety of another molecule. These cross-peaks require the distance between the related protons to be $<4 \AA$.

\section{ATIQCTPC forms hexamer of flyer-like conformation}

In order to visualize the conformation of the hexamer, the molecule of ATIQCTPC was sketched in ChemDraw 12.0 and converted to the $3 \mathrm{D}$ conformation in Chem3D 12.0, and then, the energy minimization was performed in Discovery Studio 4.2 (with a Merck molecular force field; Merck \& Co.) to obtain energy-minimized 3D conformation (Figure 3C). According to six cross-peaks of ROESY 2D ${ }^{1} \mathrm{H}$ NMR spectrum-defined hydrogen bond distances, six monomers of energy-minimized 3D conformation (Figure 3B) were manually approached and the hexamer of flyer-like conformation was obtained (Figure 3C). To clarify the distances between the protons involved in six cross-peaks, these peaks were locally amplified and provided as Figure 3D.

\section{ATIQCTPC forms nanoparticles}

\section{Nanoparticles of ATIQCTPC in various states}

The characterization of $10^{-7} \mathrm{M}$ ATIQCTPC in ultrapure water ( $\mathrm{pH} 7$; water was prepared by ultrasonic degassing and bubbling through highly pure nitrogen) was identified by TEM. Figure 4A indicates that in ultrapure water, ATIQCTPC forms particles of $32.3 \pm 14.1 \mathrm{~nm}$. The characterization of lyophilized powders of ATIQCTPC was identified by SEM. Figure 4B indicates that the lyophilized powders of ATIQCTPC resulting from $10^{-7} \mathrm{M}$ solution of ATIQCTPC in ultrapure water are the particles of diameter $47.5 \pm 21.5 \mathrm{~nm}$. The characterization of ATIQCTPC in rat plasma $\left(10^{-7} \mathrm{M}\right)$ was identified by AFM. Figure 4E indicates that in rat plasma, ATIQCTPC forms particles of height $80.6 \pm 11.0 \mathrm{~nm}$. In contrast to this, 

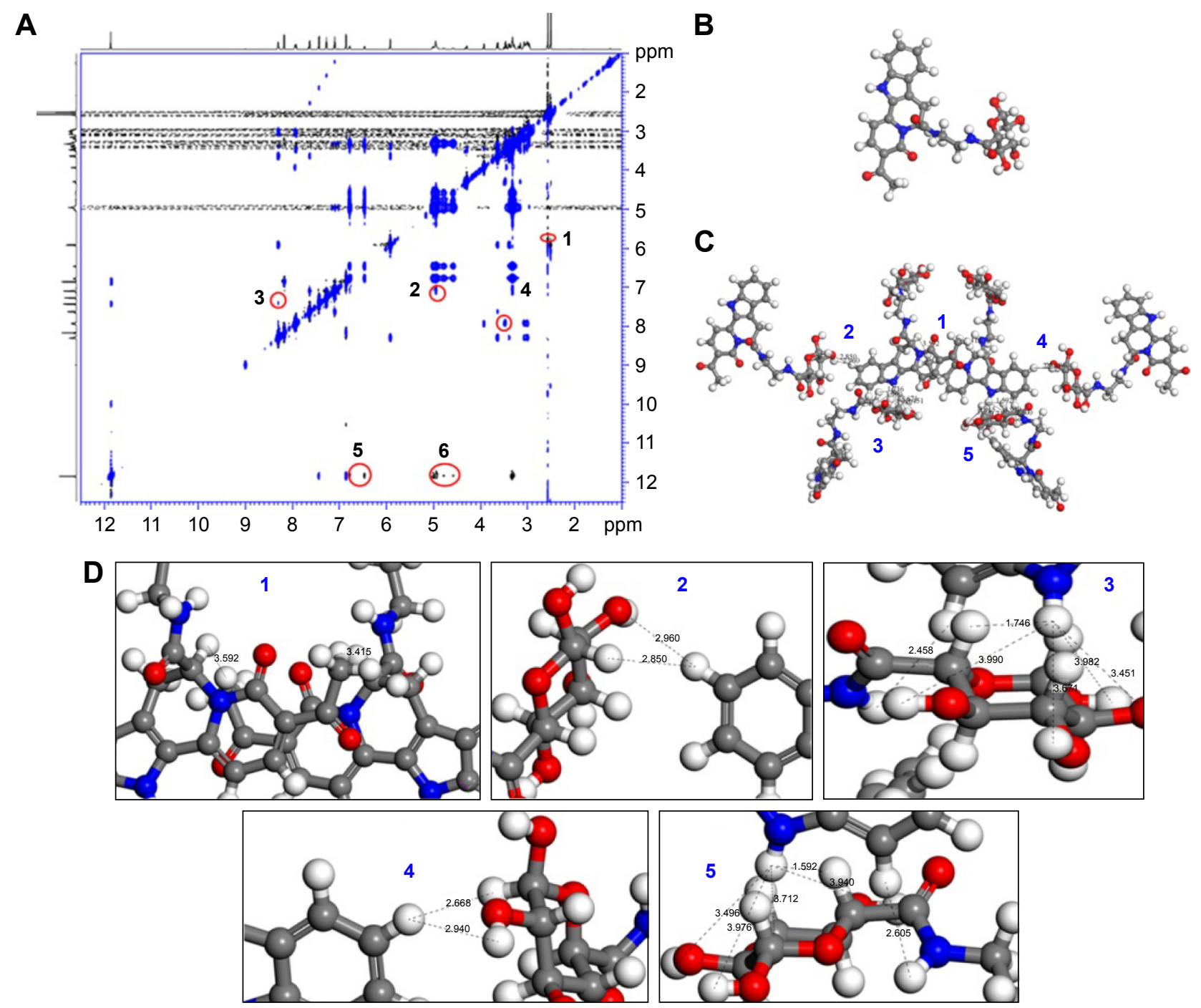

Figure 3 ROESY 2D 'H NMR spectrum, the monomer, and the hexamer conformations of ATIQCTPC.

Notes: (A) ROESY 2D 'H NMR spectrum of ATIQCTPC, which defines the approach manner of six molecules to form the hexamer. (B) Energy-minimized conformation of the monomer of ATIQCTPC. (C) Energy-minimized conformation of the hexamer of ATIQCTPC. (D) Locally amplified hydrogen bond distances in flyer-like 3D conformation of ATIQCTPC's hexamer (I 5).

Abbreviations: ROESY, rotating-frame Overhauser effect spectroscopy; NMR, nuclear magnetic resonance; ATIQCTPC, (6S)-3-acetyl-4-oxo-N-(2-(3,4,5,6-tetrahydroxytetrahydro-2H-pyran-2-carboxamido)ethyl)-4,6,7, I2-tetrahydroindolo[2,3-a]quinolizine-6-carboxamide.

Figure 4C indicates that rat plasma alone has no comparable particle. Similarly, Figure 4D indicates that NS alone shows the particles of height $330.3 \pm 10.2 \mathrm{~nm}$. The formation and the size of the nanoparticles of ATIQCTPC were further theoretically predicted with the mesoscale simulation. Figure 4F shows the calculation strategy and indicates that a nanoparticle of diameter $10.3 \mathrm{~nm}$ contains 1,338 molecules of ATIQCTPC.

\section{Aqueous ATIQCTPC is a nanosolution}

To characterize the property of the aqueous solution of ATIQCTPC, we examined the Faraday-Tyndall effect induced by $650 \mathrm{~nm}$ laser radiation and measured the zeta potential and size distribution of the particles using a Malvern Zetasizer (Nano ZS90; Malvern Instruments, Malvern, UK) with DTS (Nano) program. Gastric juice $\mathrm{pH}$ was $\sim 2$, while blood $\mathrm{pH}$ and tissue fluid $\mathrm{pH}$ were $\sim 7.0$. To explore the effect of oral administration, the blood circulation, and the tissue distribution on ATIQCTPC, the nanoproperties of ATIQCTPC in ultrapure water of $\mathrm{pH} 2.0$ and $\mathrm{pH} 7.0$ were tested. Figure $5 \mathrm{~A}$ and $\mathrm{B}$ indicates that ATIQCTPC in ultrapure water of $\mathrm{pH} 2.0$ and $\mathrm{pH} 7.0\left(10^{-7} \mathrm{M}\right)$ without $650 \mathrm{~nm}$ laser radiation are colorless and transparent solutions. Figure $5 \mathrm{C}$ and $\mathrm{D}$ indicates that ATIQCTPC in ultrapure water of $\mathrm{pH} 2.0$ and $\mathrm{pH} 7.0\left(10^{-7} \mathrm{M}\right)$ with $650 \mathrm{~nm}$ laser radiation shows Faraday-Tyndall effect. Figure 5E and $\mathrm{F}$ indicates that the 
A

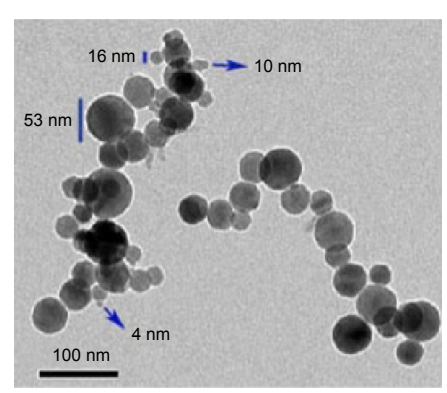

D

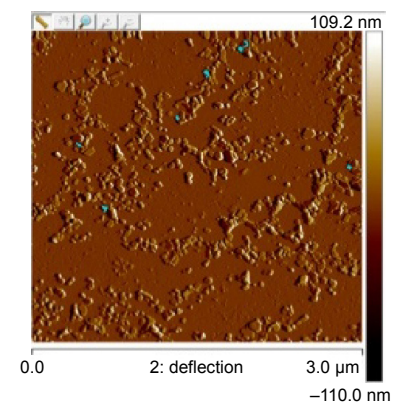

B

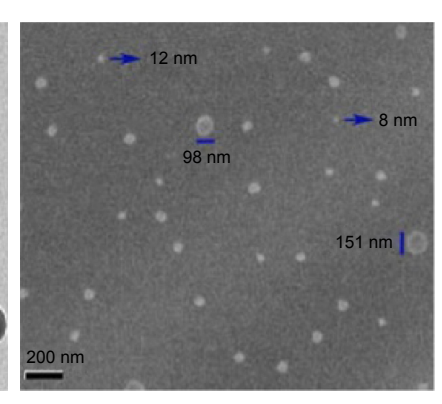

C

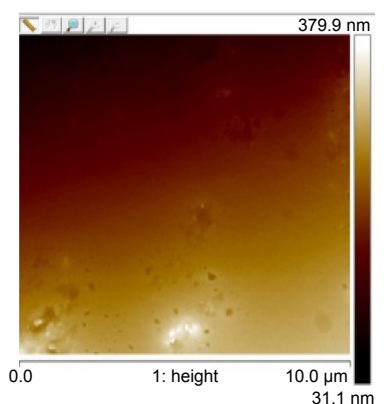

E

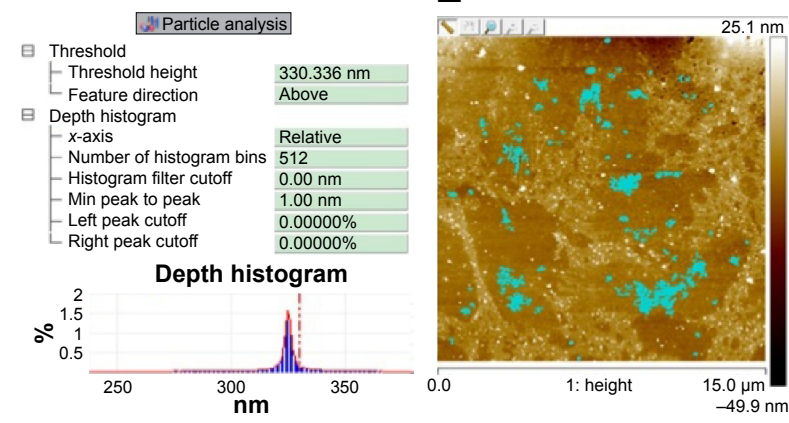

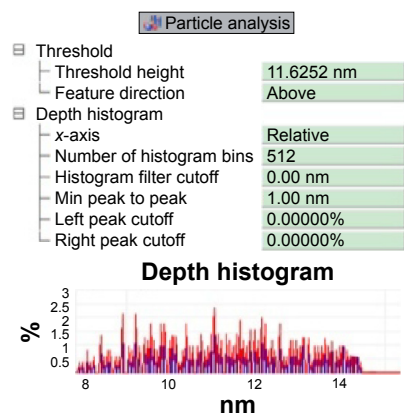

$\mathrm{nm}$

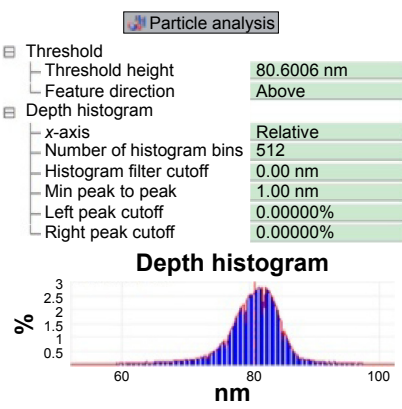

$\mathbf{F}$
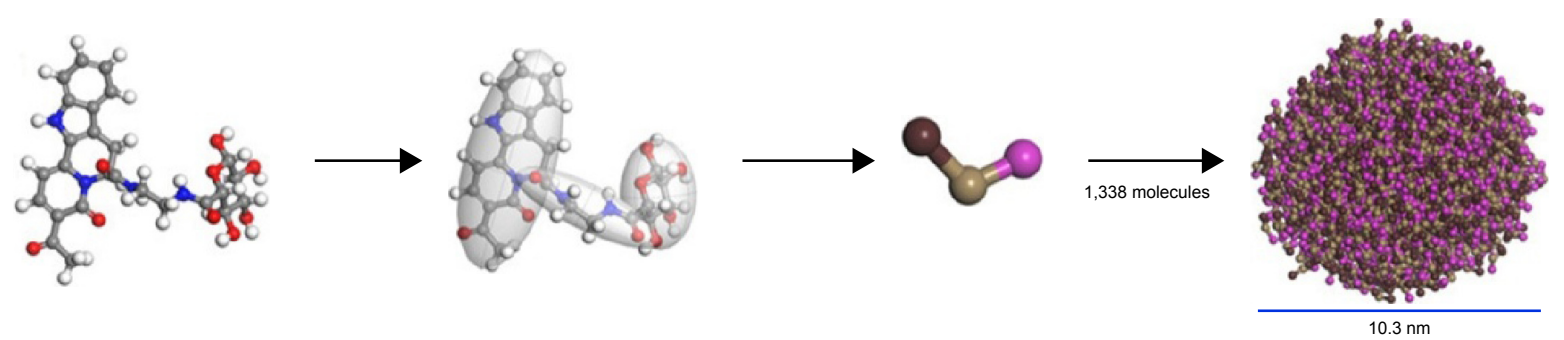

Figure 4 TEM, SEM, and AFM images of ATIQCTPC's particles.

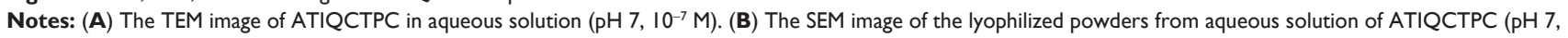
$10^{-7}$ M). (C) The AFM image of rat plasma alone; no particle could be seen. (D) The AFM image of NS alone, and the height of the particle is $330.3 \mathrm{~nm}$. (E) ATIQCTPC in rat plasma $\left(10^{-7} \mathrm{M}\right)$, and the height of the particle is $80.6 \mathrm{~nm}$. (F) Mesoscale simulation of ATIQCTPC forming a nanoparticle.

Abbreviations: TEM, transmission electron microscopy; SEM, scanning electron microscopy; AFM, atomic force microscopy; ATIQCTPC, (6S)-3-acetyl-4-oxo-N-(2-(3,4,5, 6-tetrahydroxy-tetrahydro-2H-pyran-2-carboxamido)ethyl)-4,6,7,12-tetrahydroindolo[2,3-a]quinolizine-6-carboxamide; NS, normal saline; Min, minimum.

mean sizes of the particles formed by ATIQCTPC in ultrapure water of $\mathrm{pH} 2.0$ and $\mathrm{pH} 7.0\left(10^{-7} \mathrm{M}\right)$ are $142.5 \pm 14.8 \mathrm{~nm}$ and $107.0 \pm 11.6 \mathrm{~nm}$, respectively. Figure $5 \mathrm{G}$ and $\mathrm{H}$ shows that the zeta potentials of ATIQCTPC in ultrapure water of $\mathrm{pH} 2.0$ and $\mathrm{pH} 7.0\left(10^{-7} \mathrm{M}\right)$ are 2.97 and $-21.60 \mathrm{mV}$, respectively.

\section{In vivo ATIQCTPC slows tumor growth of SI 80 mice}

The antitumor activity of ATIQCTPC was evaluated on S180 mouse model and was represented with tumor weight. Figure 6A indicates that ATIQCTPC dose $(0.001,0.01$, and $1 \mu \mathrm{mol} / \mathrm{kg}$ ) dependently slows the tumor growth of S180 mice, and the tumor weight of the mice orally treated with $0.01 \mu \mathrm{mol} / \mathrm{kg} /$ day of ATIQCTPC for 7 days is significantly lower than that of the mice orally treated with NS for 7 days $(P<0.05)$, and is equal to that of the mice orally treated with
$1 \mu \mathrm{mol} / \mathrm{kg} /$ day of ATIQC for 7 days $(P>0.05)$. This means that the minimal effective dose of ATIQCTPC to treat the tumor is 100-fold lower than that of ATIQC. Besides, at $1 \mu \mathrm{mol} / \mathrm{kg} /$ day dose, the 7-day treatment of ATIQCTPC did not induce the $\mathrm{S} 180$ mice showing bleeding reaction.

\section{In vivo ATIQCTPC inhibits rat thrombosis}

The anti-thrombotic activity of ATIQCTPC was evaluated on a rat thrombus model and was represented with thrombus weight. Figure 6D indicates that $0.01 \mu \mathrm{mol} / \mathrm{kg}$ of ATIQCTPC effectively inhibits rats to develop thrombi, and the thrombus weight of the rats orally treated with $0.01 \mu \mathrm{mol} /$ $\mathrm{kg}$ of ATIQCTPC is significantly lower than that of the rats orally treated with NS $(P<0.01)$, and is equal to that of the rats orally treated with $1 \mu \mathrm{mol} / \mathrm{kg}$ of ATIQC $(P>0.05)$. 


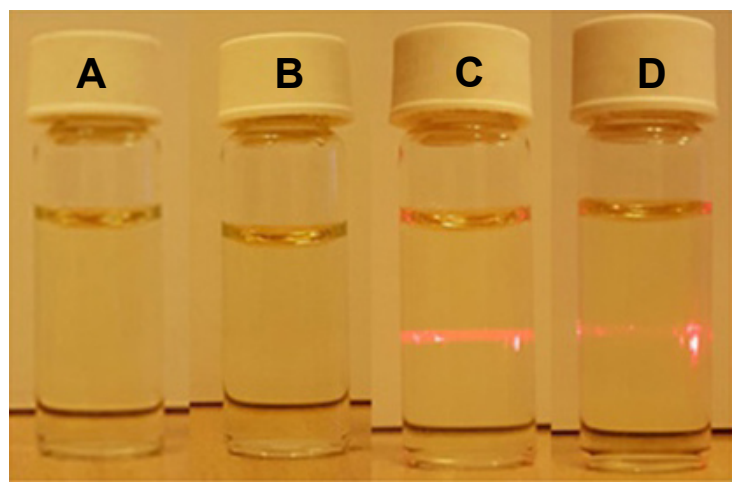

$\mathbf{E}$
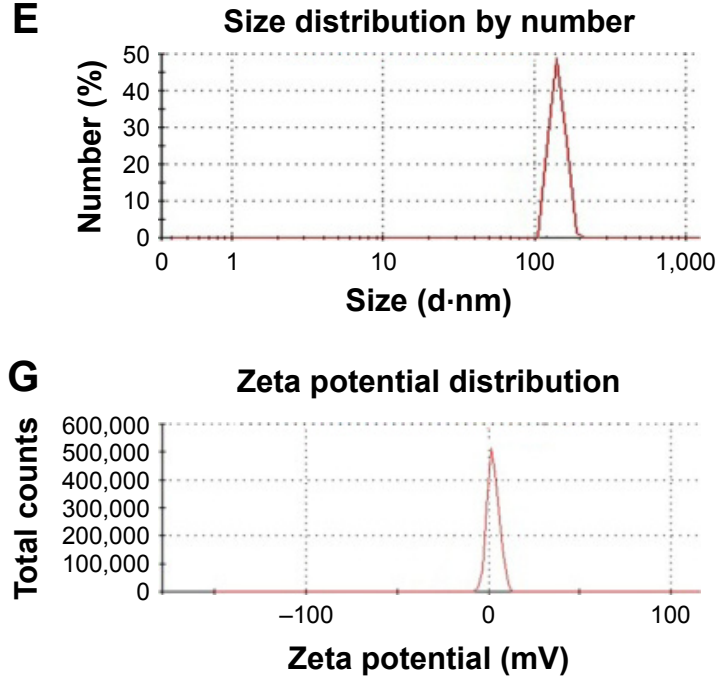

$\mathbf{F}$
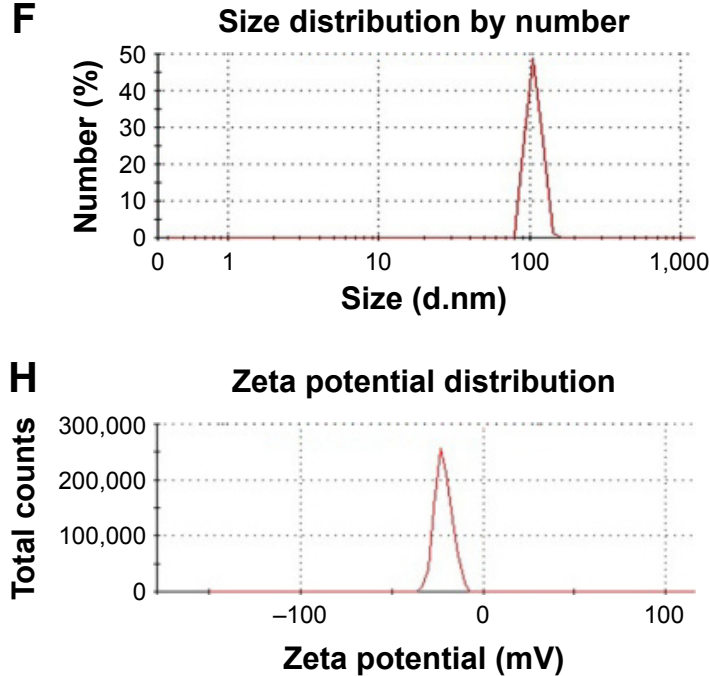

Figure 5 Faraday-Tyndall effect, size, and zeta potential of ATIQCTPC in ultrapure water of $\mathrm{pH} 2.0$ and pH 7.0.

Notes: (A) ATIQCTPC in ultrapure water of $\mathrm{pH} 2.0\left(10^{-7} \mathrm{M}\right)$ without $650 \mathrm{~nm}$ laser radiation. (B) ATIQCTPC in ultrapure water of $\mathrm{pH} 7.0\left(\mathrm{I} 0^{-7} \mathrm{M}\right)$ without $650 \mathrm{~nm}$ laser radiation. (C) ATIQCTPC in ultrapure water of $\mathrm{pH} 2.0\left(10^{-7} \mathrm{M}\right)$ with $650 \mathrm{~nm}$ laser radiation. (D) ATIQCTPC in ultrapure water of $\mathrm{pH} 7.0\left(10^{-7} \mathrm{M}\right)$ with $650 \mathrm{~nm}$ laser radiation. (E) Size distribution of ATIQCTPC in ultrapure water of $\mathrm{pH} 2.0\left(10^{-7} \mathrm{M}\right)$. (F) Size distribution of ATIQCTPC in ultrapure water of pH 7.0 (I0-7 M). (G) Zeta potential of ATIQCTPC in ultrapure water of $\mathrm{pH} 2.0\left(10^{-7} \mathrm{M}\right)$. $(\mathbf{H})$ Zeta potential of ATIQCTPC in ultrapure water of $\mathrm{pH} 7.0\left(10^{-7} \mathrm{M}\right)$.

Abbreviation: ATIQCTPC, (6S)-3-acetyl-4-oxo-N-(2-(3,4,5,6-tetrahydroxytetrahydro-2H-pyran-2-carboxamido)ethyl)-4,6,7,I2-tetrahydroindolo[2,3-a]quinolizine-6-carboxamide.

This means that the anti-thrombotic dose of ATIQCTPC is 100 -fold lower than that of ATIQC. Figure $6 \mathrm{D}$ also indicates that the thrombus weight of the rats orally treated with $0.01 \mu \mathrm{mol} / \mathrm{kg}$ of ATIQCTPC is equal to that of the rats orally treated with $16.7 \mu \mathrm{mol} / \mathrm{kg}$ of aspirin $(P>0.05)$. This means that the anti-thrombotic dose of ATIQCTPC is 1,670-fold lower than that of aspirin.

\section{ATIQCTPC decreases serum TNF- $\alpha$ and IL-8 of SI 80 mice}

It is well known that serum TNF- $\alpha$ and IL-8 of cancer patients are higher than those of healthy controls. ${ }^{29,30}$ These findings lead to the determination of serum TNF- $\alpha$ and IL-8 of S180 mice orally treated with ATIQCTPC. Figure 6B and $\mathrm{C}$ indicates that the serum concentrations of TNF- $\alpha$ and IL-8 of S180 mice orally treated with $0.01 \mu \mathrm{mol} / \mathrm{kg} / \mathrm{day}$ of ATIQCTPC are significantly lower than those of the S180 mice orally treated with NS $(P<0.05)$, correlating the downregulation of serum TNF- $\alpha$ and IL-8 with the slower tumor growth.

\section{ATIQCTPC downregulates P-selectin expression}

The importance of P-selectin for thrombus formation in human beings has been demonstrated ${ }^{31}$ and leads to evaluating the effects of ATIQCTPC on P-selectin expression in vitro and in vivo. Figure $6 \mathrm{~F}$ indicates that $1 \mu \mathrm{M}$ of ATIQCTPC effectively decreases AA-activated platelets to express P-selectin (comparing to NS, $P<0.05$ ). Figure $6 \mathrm{E}$ indicates that serum concentration of $\mathrm{P}$-selectin of the treated rats and the activity are 100-fold higher than those of ATIQC. Figure $6 \mathrm{~F}$ indicates that at $1.00,0.01$, and $0.001 \mu \mathrm{mol} / \mathrm{kg}$ of doses of ATIQCTPC effectively decrease the serum $\mathrm{P}$-selectin of the treated rats. The serum P-selectin of the rats treated with $0.001 \mu \mathrm{mol} / \mathrm{kg}$ of ATIQCTPC is significantly lower than that of the rats treated with NS $(P<0.05)$. 
A

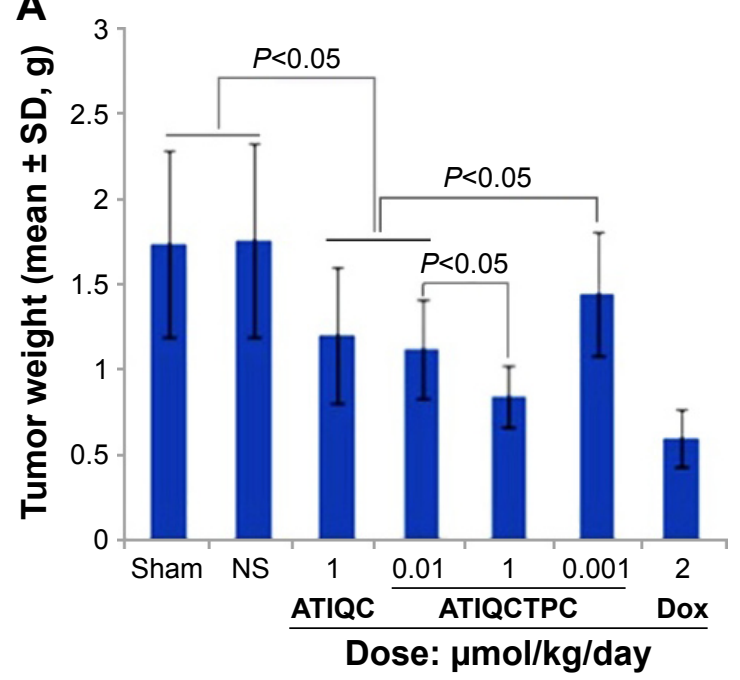

B

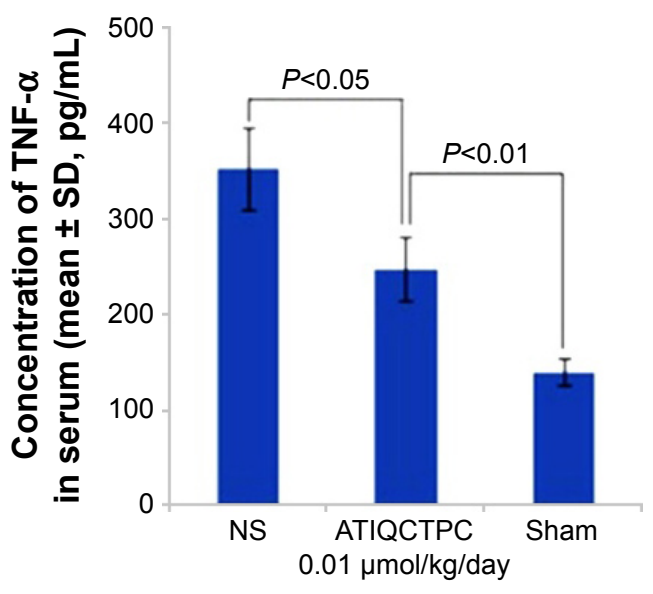

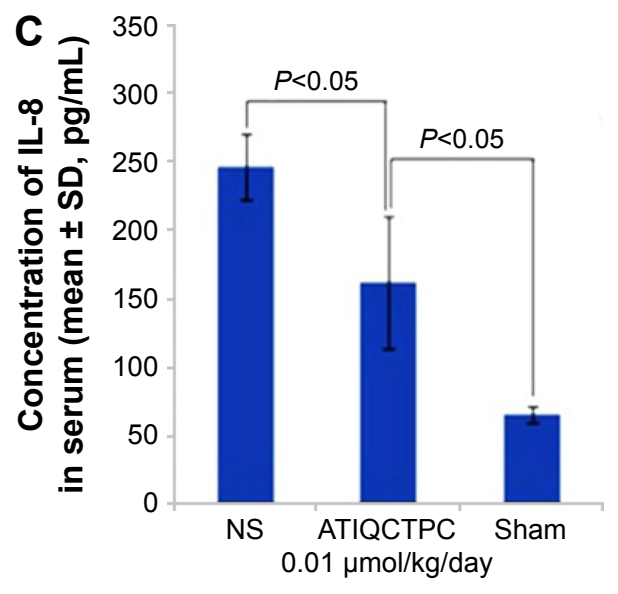
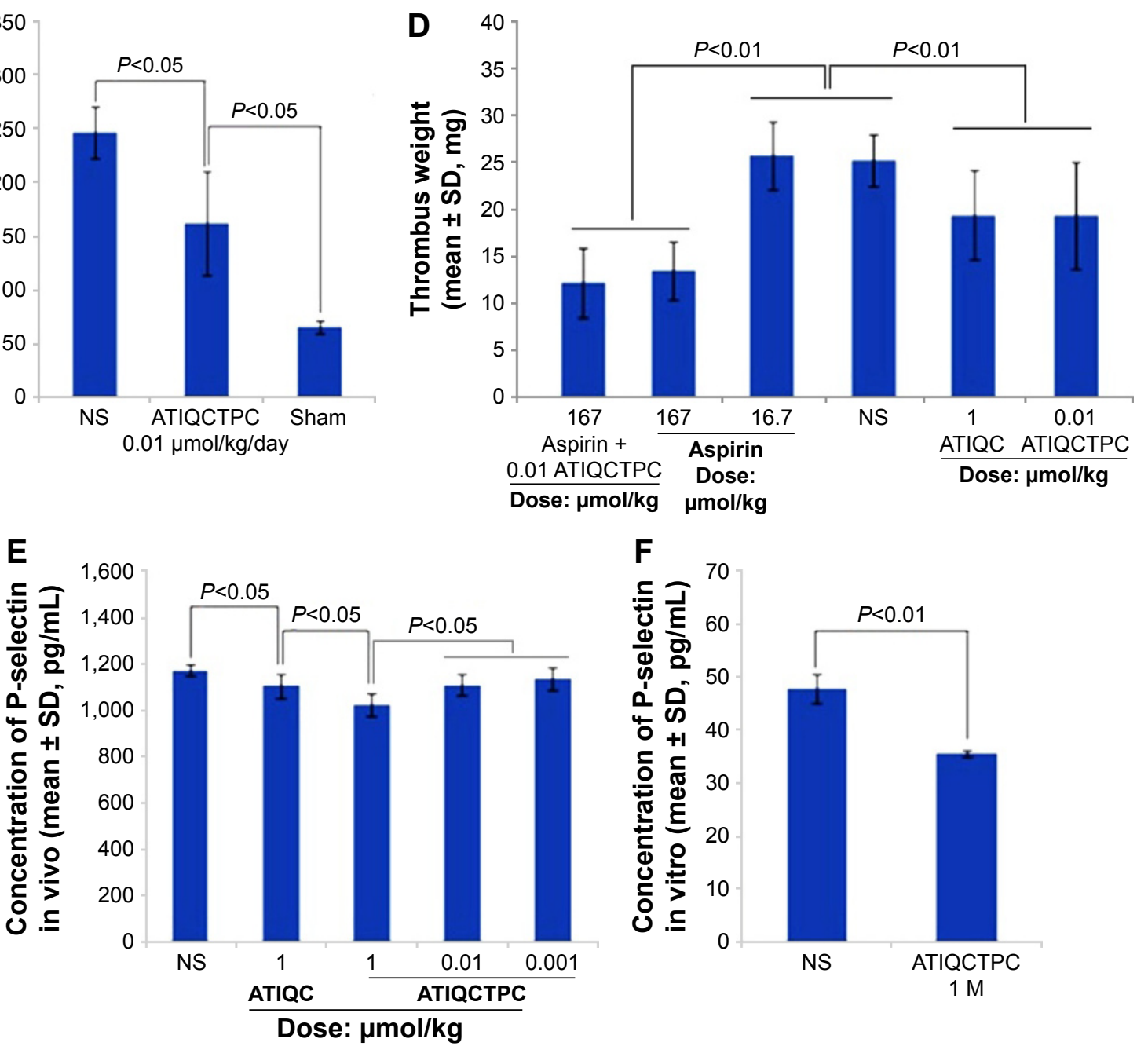

Figure 6 Effect of oral ATIQCTPC on tumor weight of SI 80 mice, thrombosis of rats, serum TNF- $\alpha$ and IL- 8 of SI 80 mice, P-selectin expression of the platelets of the rats receiving anti-thrombotic therapy, and P-selectin expression of the platelets in vitro.

Notes: (A) In vivo oral ATIQCTPC dose dependently inhibits the growth of the tumor of SI80 mice ( $n=12$ ). (B) TNF- $\alpha$ in the serum of SI 80 mice treated with NS and $0.01 \mu \mathrm{mol} / \mathrm{kg}$ of ATIQCTPC for 10 consecutive days $(n=12)$. (C) IL-8 in the serum of SI 80 mice treated with NS and $0.01 \mu \mathrm{mol} / \mathrm{kg}$ of ATIQCTPC for I0 consecutive days $(n=12)$. (D) Antithrombotic activity of ATIQCTPC $(n=12)$. (E) In vivo P-selectin expression of the platelets of the rats treated with NS, ATIQC (I $\mu$ mol/kg), and ATIQCTPC $(\mathrm{I}, 0.0 \mathrm{I}$, and $0.00 \mathrm{I} \mu \mathrm{mol} / \mathrm{kg} ; \mathrm{n}=\mathrm{I} 2$ ). (F) P-selectin expression of $\mathrm{AA}$-activated platelets treated with I $\mu M$ of ATIQCTPC in vitro ( $\mathrm{n}=5$ ).

Abbreviations: ATIQCTPC, (6S)-3-acetyl-4-oxo-N-(2-(3,4,5,6-tetrahydroxytetrahydro-2H-pyran-2-carboxamido)ethyl)-4,6,7,I2-tetrahydroindolo[2,3-a]quinolizine-6carboxamide; TNF- $\alpha$, tumor necrosis factor- $\alpha$; IL-8, interleukin-8; n, number; NS, normal saline; ATIQC, (S)-3-acetyl-4-oxo-tetrahydroindolo[2,3-a]quinolizine-6-carboxylic acid; AA, arachidonic acid; SD, standard deviation. 


\section{ATIQCTPC targeting tumor tissue and releasing ATIQC}

To understand the benefits of ATIQCTPC in tumor therapy, the extracts of the homogenates of the brain, the heart, the spleen, the liver, the kidney, and the tumor tissue of the S180 mice treated with NS and $1 \mu \mathrm{mol} / \mathrm{kg} /$ day of ATIQCTPC for 7 consecutive days received ESI-MS analysis. Figure 7A shows the FT-MS spectrum of the extract of the tumor tissue of S180 mice treated with ATIQCTPC and gives
ATIQC-related peaks, but not ATIQCTPC-related peaks, at 323.11825 (the mass of ATIQC molecule plus H), 345.11243 (the mass of ATIQC molecule plus Na), and 361.18996 (the mass of ATIQC molecule plus $\mathrm{K}$ ); ie, in the tumor tissue, ATIQCTPC releases ATIQC. Figure 7C-G shows the FT-MS spectra of the extracts of the brain, the heart, the spleen, the liver and the kidney of S180 mice treated with ATIQCTPC and gives no ion peaks related to ATIQCTPC and ATIQC, suggesting that ATIQCTPC does not accumulate in these
A

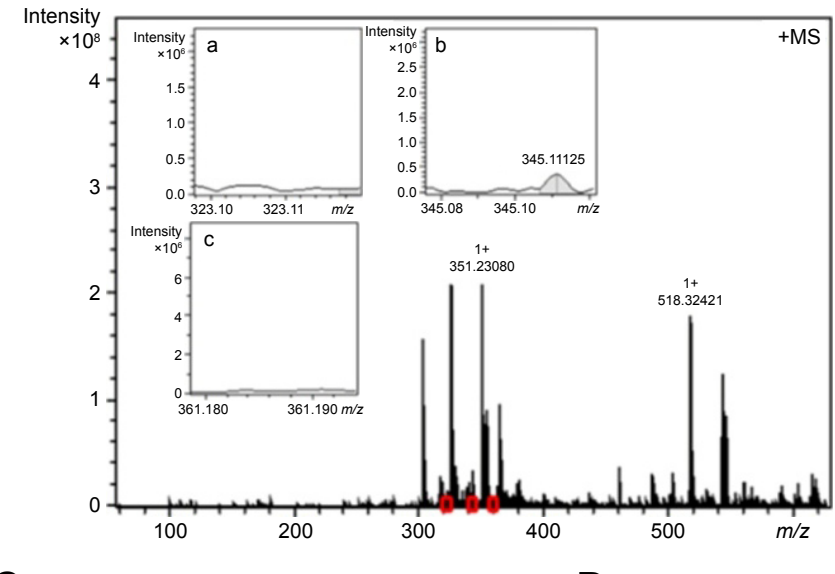

C

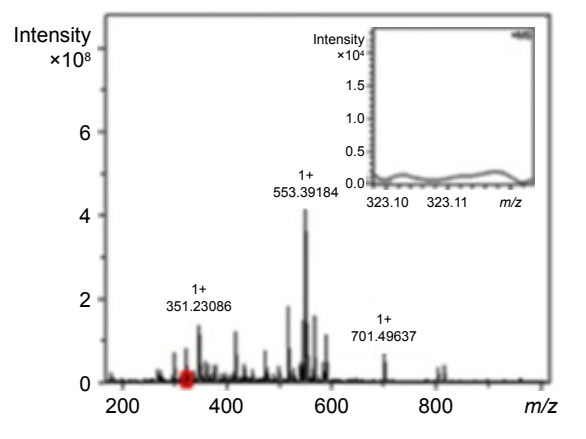

D
B

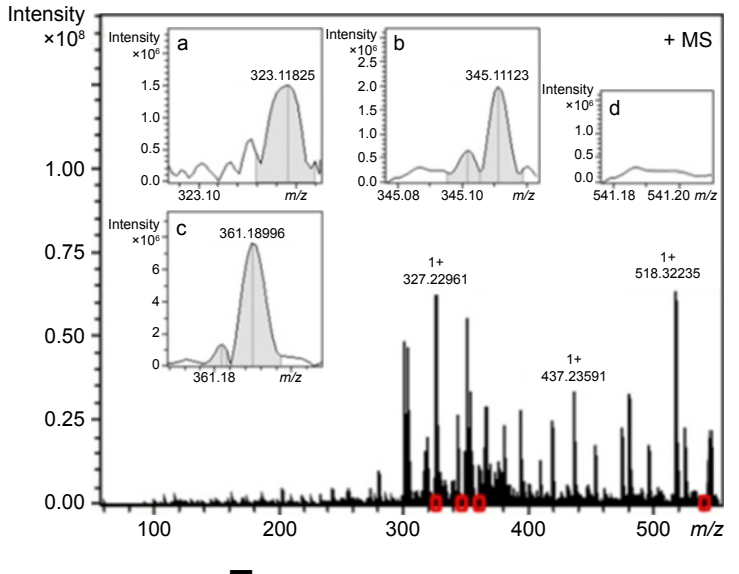

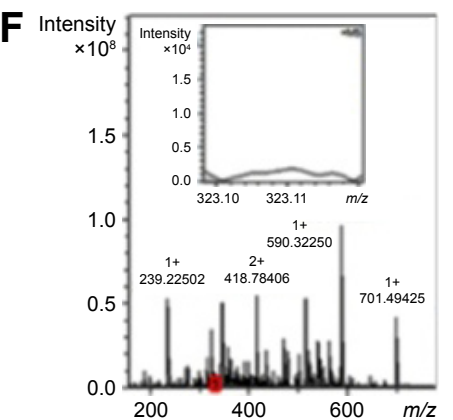

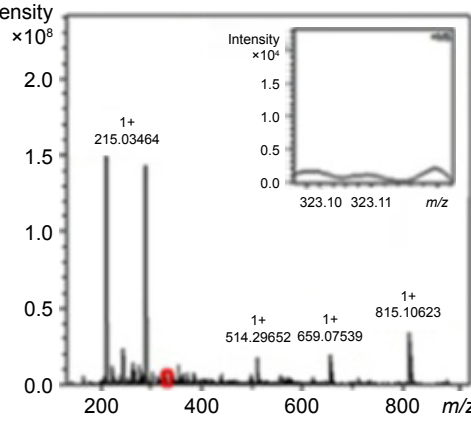

E
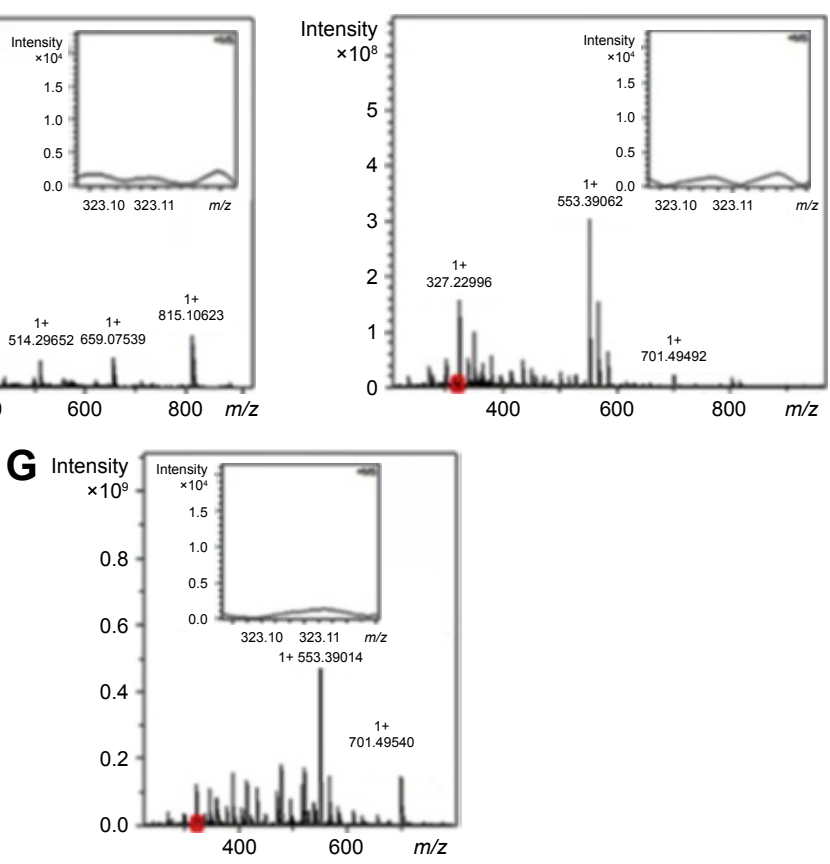

Figure 7 ESI-MS spectra of the extracts of the tumor, brain, heart, spleen, liver, and kidney tissues of the SI80 mice treated with I $\mu$ mol/kg of ATIQCTPC for I0 consecutive days. Notes: (A) ESI-MS spectrum of the extract of the tumor tissue of the SI80 mice treated with I $\mu \mathrm{mol} / \mathrm{kg}$ of ATIQCTPC for 10 consecutive days, a c denote the MS area of ATIQCTPC-related peaks. (B) ESI-MS spectrum of the extract of the tumor tissue of the SI80 mice treated with NS for 10 consecutive days, a $\sim$ denoted the MS area of ATIQCTPC-related peaks. (C) ESI-MS spectrum of the extract of the brain tissue of the SI80 mice treated with I $\mu$ mol/kg of ATIQCTPC for I0 consecutive days. (D) ESI-MS spectrum of the extract of the heart tissue of the SI 80 mice treated with I $\mu \mathrm{mol} / \mathrm{kg}$ of ATIQCTPC for 10 consecutive days. (E) ESI-MS spectrum of the extract of the spleen tissue of the SI 80 mice treated with I $\mu \mathrm{mol} / \mathrm{kg}$ of ATIQCTPC for I 0 consecutive days. (F) ESI-MS spectrum of the extract of the liver tissue of the SI 80 mice treated with I $\mu \mathrm{mol} / \mathrm{kg}$ of ATIQCTPC for 10 consecutive days. (G) ESI-MS spectrum of the extract of the kidney tissue of the SI80 mice treated with I $\mu$ mol/kg of ATIQCTPC for I0 consecutive days. Abbreviations: ESI-MS, electrospray ionization mass spectrometry; ATIQCTPC, (6S)-3-acetyl-4-oxo-N-(2-(3,4,5,6-tetrahydroxytetrahydro-2H-pyran-2-carboxamido) ethyl)-4,6,7,I 2-tetrahydroindolo[2,3-a]quinolizine-6-carboxamide; NS, normal saline. 
organs. Figure 7B shows the FT-MS spectrum of the extract of the tumor tissue of S180 mice treated with NS and gives no ATIQCTPC- and ATIQC-related ion peaks. Thus, the ion peaks of ATIQC of Figure 7A result from the release of ATIQCTPC.

\section{Discussion}

As demonstrated by Scheme 1, the yields of most reactions are acceptable, and the HPLC purity of ATIQCTPC is $98.9 \%$. Therefore, the procedures of eight-step reactions of Scheme 1 are suitable for preparing ATIQCTPC.

FT-MS spectrum of ATIQCTPC gives the ions of hexamer, pentamer, trimer, dimer, and monomer, and the qCID spectra show that the pentamer, trimer, dimer, and monomer result from the fragmentation of the hexamer. Thus, the spectra evidence that the hexamer can be easily fragmented to form the monomer, dimer, trimer and pentamer. This leads to a hypothesis of molecular associations, ie, the association of one monomer with one monomer to form a dimer, one monomer with one dimer to form a trimer, one monomer with two dimers to form a pentamer, and one monomer with one pentamer to form a hexamer.

Six cross-peaks in the NOESY spectrum define the distances between quinolizine methyl-H and quinolizine methane- $\mathrm{H}$, indole $5-\mathrm{H}$ and pyran $1-\mathrm{H}$, indole $7-\mathrm{H}$ and quinolizine amide $\mathrm{H}$, pyran amide $\mathrm{H}$ and pyran $3-\mathrm{H}$, pyrrole $\mathrm{H}$ and the $\mathrm{H}$ of 1,2,3,4-tetrahydroxyls of pyran are $<4 \AA$, thereby defining a manner of molecular associations to form a hexamer (Figure 3D). By following this manner, six monomers of minimal energy conformation of Figure $3 \mathrm{~B}$ could be approached, and the formed hexamer should have a flyer-like conformation of Figure 3C.

TEM, SEM, and AFM images visualize that in water, lyophilized state, and rat plasma, ATIQCTPC existed as the particles of size $32.3-80.6 \mathrm{~nm}$. In particular, in rat plasma, ATIQCTPC existed as the particles of height $80.6 \mathrm{~nm}$. This scale should benefit the nanoparticles to avoid the macrophages being entrapped in the blood circulation and hence reaching the target tissue. ${ }^{22}$ The mesoscale simulation predicts that a nanoparticle of diameter $10.3 \mathrm{~nm}$ contains 1,338 ATIQCTPC molecules. Accordingly, the smallest nanoparticle of diameter $10 \mathrm{~nm}$ of Figure 4A should contain 1,299 ATIQCTPC molecules. The Faraday-Tyndall effect, the zeta potential, and the size distribution of ATIQCTPC in ultrapure water of $\mathrm{pH} 2.0$ and $\mathrm{pH} 7.0$ emphasize the nanoproperty of these aqueous solutions. The mean size of the particles of ATIQCTPC in ultrapure water of $\mathrm{pH} 2.0$ is larger than that of the particles of ATIQCTPC in ultrapure water of $\mathrm{pH}$ 7.0. This matches that the zeta potential of ATIQCTPC in ultrapure water of $\mathrm{pH} 2.0$ is smaller than that of ATIQCTPC in ultrapure water of $\mathrm{pH}$ 7.0. As $\mathrm{pH} 2.0$ is the gastric juice $\mathrm{pH}$ and $\mathrm{pH} 7.0$ is the blood and the tissue fluid $\mathrm{pH}$, the nanoproperty of ATIQCTPC in ultrapure water of $\mathrm{pH} 2.0$ should benefit the oral administration of ATIQCTPC, while the nanoproperty of ATIQCTPC in ultrapure water of $\mathrm{pH} 7.0$ should benefit the blood delivery and the tissue transport.

The antitumor and anti-thrombotic assays show that ATIQCTPC not only slows the tumor growth of S180 mice but also blocks the rats to form thrombi. Thus, ATIQCTPC has dual actions. As thrombosis is one of the serious complications in cancer patients, the dual actions support that as an antitumor agent, ATIQCTPC is able to prevent cancer patients from suffering from thrombosis. ${ }^{32,33}$

As mentioned earlier, the serum concentrations of TNF- $\alpha$ and IL- 8 of the S180 mice orally treated with $0.01 \mu \mathrm{mol} / \mathrm{kg} /$ day of ATIQCTPC are significantly lower than those of the S180 mice orally treated with NS. The findings of ATIQCTPC effectively downregulating serum TNF- $\alpha$ and IL- 8 of S180 mice lead to a hypothesis that via decreasing serum TNF- $\alpha$ and IL-8, ATIQCTPC slows tumor growth of S180 mice. ${ }^{34-36}$

In vivo, ATIQCTPC downregulates the thrombosis in rats to express P-selectin. In vitro, ATIQCTPC downregulates AA-activated rat platelets expression of P-selectin. The docking investigation identifies ATIQCTPC to be a desirable ligand of $\mathrm{P}$-selectin. The findings imply that $\mathrm{P}$-selectin is a target of ATIQCTPC.

The FT-MS spectrum of the extract of the tumor tissue of S180 mice treated with ATIQCTPC, but not with NS, gives ATIQC-related ion peaks, suggesting that in the tumor tissue, ATIQCTPC releases ATIQC. The FT-MS spectra of the extracts of the brain, the heart, the spleen, the liver, and the kidney of S180 mice treated with ATIQCTPC give no ion peaks related to ATIQCTPC and ATIQC, suggesting that ATIQCTPC does not accumulate in these vital organs. Therefore, by targeting P-selectin, ATIQCTPC specifically accumulates in the tumor tissue and releases ATIQC wherein.

The specific accumulation of ATIQCTPC in the tumor tissue leads to excellent in vivo antitumor activity, such that the antitumor activity of ATIQCTPC is 100-fold higher than that of ATIQC. In respect of the relationship of P-selectin and thrombosis, ATIQCTPC targeting P-selectin and downregulating $\mathrm{P}$-selectin expression should benefit the thrombus therapy, such that the anti-thrombotic activity of ATIQCTPC is 1,670-fold higher than that of aspirin. 


\section{Conclusion}

Using ethane-1,2-diamine as a bridge, the antitumor active ATIQC was conjugated with D-glucuronic acid and a molecule, ATIQCTPC, having antitumor and anti-thrombotic actions was presented. With D-glucuronic acid as a tumortargeting carrier, ATIQCTPC can specifically accumulate in the tumor tissue, not in the vital organs. The excellent antitumor activity in vivo was correlated with the downregulation of serum TNF- $\alpha$ and IL- 8 of S180 mice treated with ATIQCTPC. As a desirable ligand of P-selectin, ATIQCTPC exhibited high antitumor and anti-thrombotic activities in vivo. TEM, SEM, AFM, Faraday-Tyndall effect, zeta potential, and size distribution measurements consistently evidenced ATIQCTPC forming the nanoparticles that could be safely delivered in blood circulation. It is worthy of mention that a single-dose acute aspirin therapy is not so relevant to clinical situations; 1-week anti-thrombotic assays of ATIQCTPC should be done additionally.

\section{Acknowledgment}

We thank the Natural Science Foundation of China (81273379, 81270046, 81373264, 81373265, and 81673303), the Project of Construction of Innovative Teams and Teacher Career Development for Universities and Colleges Under Beijing Municipality, Beijing Natural Science Foundation (7162025), Innovation Capability Enhancement Program (201310025008), the 863 Program (2015AA020902), Beijing Municipal Science and Technology Commission (Z141100002114049), 2014000026833ZK23, and KZ201610025029 for financial support.

\section{Disclosure}

The authors report no conflicts of interest in this work.

\section{References}

1. Stebbing J, Jones A, Barrett-Lee P. Cardiotoxicity and anthracyclines. Breast Cancer Res Treat. 2008;107(3):451-453.

2. Octavia Y, Tocchetti CG, Gabrielson KL, Janssens S, Crijns HJ, Moens AL. Doxorubicin-induced cardiomyopathy: from molecular mechanisms to therapeutic strategies. J Mol Cell Cardiol. 2012;52(6): $1213-1225$.

3. Tacar O, Sriamornsak P, Dass CR. Doxorubicin: an update on anticancer molecular action, toxicity and novel drug delivery systems. $J$ Pharm Pharmacol. 2013;65(2):157-170.

4. Park H, Tsutsumi H, Mihara H. Cell-selective intracellular drug delivery using doxorubicin and $\alpha$-helical peptides conjugated to gold nanoparticles. Biomaterials. 2014;35(10):3480-3487.

5. El-Sheikh AA, Morsy MA, Mahmoud MM, Rifaai RA. Protective mechanisms of coenzyme-Q10 may involve up-regulation of testicular P-glycoprotein in doxorubicin-induced toxicity. Environ Toxicol Pharmacol. 2014;37(2):772-781.

6. Cao S, Durrani FA, Tóth K, Rustum YM. Se-methylselenocysteine offers selective protection against toxicity and potentiates the antitumour activity of anticancer drugs in preclinical animal models. $\mathrm{Br} J$ Cancer. 2014;110(7):1733-1743.
7. Tortorella S, Karagiannis TC. Transferrin receptor-mediated endocytosis: a useful target for cancer therapy. J Membr Biol. 2014;247(4): 291-307.

8. Rosas-García VM, Alfaro-López T. Computational study on the dimerization of indoloquinolizines. J Mol Struct Theochem. 2005; 719:225-228.

9. Li S, Wang Y, Wang F, et al. PZL318: forming fluorescent nanoparticles capable of tracing their interactions with cancer cells and activated platelets, slowing tumor growth and inhibiting thrombosis. Int J Nanomed. 2015;10:5273-5292.

10. Zhao M, Wang C, Guo M, et al. Synthesis of 6-amino acid substituted 4,6,7, 12-tetrahydro-4-oxoindolo[2,3-a]quinolizines. J Prakt Chem. 1999:341(7):691-694.

11. Solis-Maldonado C, Quintanilla-Licea R, Tamez-Guerra R, RodríguezPadilla C, Gomez-Flores R. Differential effects of synthetic indoloquinolizines on in vitro rat lymphocyte and macrophage functions. Int Immunopharmacol. 2003;3(9):1261-1271.

12. Mallick A, Haldar B, Sengupta S, et al. 7-Hydroxy-4-methyl-8(4'-methylpipera-zine-1'-yl)methyl coumarin: an efficient probe for fluorescence resonance energy transfer to a bioactive indoloquinolizine system. J Lumin. 2006;118(2):165-172.

13. Sankar MG, Mantilli L, Bull J, et al. Stereoselective synthesis of a natural product inspired tetrahydroindolo[2,3-a]quinolizine compound library. Bioorg Med Chem. 2015;23(11):2614-2620.

14. Wojcieszak R, Cuccovia IM, Silva MA, et al. Selective oxidation of glucose to glucuronic acid by cesium-promoted gold nanoparticle catalyst. J Mol Catal A Chem. 2016;422:35-42.

15. Lewis SS, Hutchinson MR, Zhang Y, et al. Glucuronic acid and the ethanol metabolite ethyl-glucuronide cause toll-like receptor 4 activation and enhanced pain. Brain Behav Immun. 2013;30:24-32.

16. Zhang R, Chen S, Wang X, et al. Synthesis and DNA-binding properties of novel DNA cyclo-intercalators containing purine-glucuronic acid hybrids. Carbohydr Res. 2016;429:48-53.

17. Sánchez Lafarga AK, Pacheco Moisés FP, Gurinov A, Ortiz GG, Carbajal Arízaga GG. Dual responsive dysprosium-doped hydroxyapatite particles and toxicity reduction after functionalization with folic and glucuronic acids. Mater Sci Eng C. 2015;48:541-547.

18. Andrade GP, Lima MA, de Souza AA, et al. A heparin-like compound isolated from a marine crab rich in glucuronic acid 2-O-sulfate presents low anticoagulant activity. Carbohydr Polym. 2013;94(1):647-654.

19. Nelwamondo SMM, Moloto MJ, Krause RW, et al. Direct synthesis of water soluble $\mathrm{CuS}$ and $\mathrm{CdS}$ nanocrystals with hydrophilic glucuronic and thioglycolic acids. Mater Res Bull. 2012;47(12):4392-4397.

20. Tavano L, Aiello R, Ioele G, et al. Niosomes from glucuronic acidbased surfactant as new carriers for cancer therapy: preparation, characterization and biological properties. Colloids Surf B Biointerfaces. 2014;118:7-13.

21. Roffler SR, Wang SM, Chern JW, et al. Anti-neoplastic glucuronide prodrug treatment of human tumor cells targeted with a monoclonal antibody-enzyme conjugate. Biochem Pharmacol. 1991;42(10): 2062-2065.

22. Fujita Y, Mie M, Kobatake E. Construction of nanoscale protein particle using temperature-sensitive elastin-like peptide and polyaspartic acid chain. Biomaterials. 2009;30(20):3450-3457.

23. Muzzalupo R, Tavano L, La Mesa C. Alkyl glucopyranoside-based niosomes containing methotrexate for pharmaceutical applications: evaluation of physico-chemical and biological properties. Int J Pharm. 2013;458(1):224-229

24. Blanzat M, Massip S, Speziale V, et al. First example of helices and tubules in aqueous solution of a new fluorescent catanionic sugar surfactant. Langmuir. 2001;17(11):3512-3514.

25. Dufes C, Schätzlein AG, Tetley L, et al. Niosomes and polymeric chitosan based vesicles bearing transferrin and glucose ligands for drug targeting. Pharm Res. 2000;17(10):1250-1258.

26. Zhu H, Wang Y, Zhao M, et al. Energy minimized crystal structures of P-selectins based on molecular dynamics simulation: leading to two average structures capable of designing anti-thrombotic agents. Medchemcomm. 2013;4:1066-1072. 
27. Feng Q, Zhao M, Gan T, et al. DHDMIQK(KAP): a novel nano-delivery of dihydroxyltetrahydroisoquinoline-3-carboxylic acid and KPAK towards thrombus. J Mater Chem B. 2016;4:5991-6003.

28. Jin S, Wang Y, Zhu H, et al. Nano-sized aspirin-Arg-Gly-Asp-Val: delivery of aspirin to thrombus by a target carrier Arg-Gly-Asp-Val tetrapeptide. ACS Nano. 2013;7:7664-7673.

29. Egberts JH, Cloosters V, Noack A, et al. Anti-tumor necrosis factor therapy inhibits pancreatic tumor growth and metastasis. Cancer Res. 2008;68(5):1443-1450.

30. Sugimoto M, Yamaoka Y, Furuta T. Influence of interleukin polymorphisms on development of gastric cancer and peptic ulcer. World $J$ Gastroenterol. 2010;16(10):1188-1200.

31. Chelliah R, Lucking AJ, Tattersall L, et al. P-selectin antagonism reduces thrombus formation in humans. J Thromb Haemost. 2009; 7(11):1915-1919.
32. Kanz R, Vukovich T, Vormittag R, et al. Thrombosis risk and survival in cancer patients with elevated C-reactive protein. J Thromb Haemost. 2011;9(1):57-63.

33. Sallah S, Wan JY, Nguyen NP. Venous thrombosis in patients with solid tumors: determination of frequency and characteristics. Thromb Haemost. 2002;87(4):575-579.

34. van Aken BE, Reitsma PH, Rosendaal FR. Interleukin 8 and venous thrombosis: evidence for a role of inflammation in thrombosis. $\mathrm{Br} J$ Haematol. 2002;116(1):173-177.

35. Wakefield TW, Greenfiel LJ, Rolfe MW, et al. Inflammatory and procoagulant mediator interactions in an experimental baboon model of venous thrombosis. Thromb Haemost. 1993;69(2):164-172.

36. Fox AE, Kahn SR. The relationship between inflammation and venous thrombosis. A systematic review of clinical studies. Thromb Haemost. 2005;94(2):362-365.
International Journal of Nanomedicine

\section{Publish your work in this journal}

The International Journal of Nanomedicine is an international, peerreviewed journal focusing on the application of nanotechnology in diagnostics, therapeutics, and drug delivery systems throughout the biomedical field. This journal is indexed on PubMed Central, MedLine, CAS, SciSearch ${ }^{\circledR}$, Current Contents ${ } /$ Clinical Medicine,

\section{Dovepress}

Journal Citation Reports/Science Edition, EMBase, Scopus and the Elsevier Bibliographic databases. The manuscript management system is completely online and includes a very quick and fair peer-review system, which is all easy to use. Visit http://www.dovepress.com/ testimonials.php to read real quotes from published authors.

Submit your manuscript here: http://www.dovepress.com/international-journal-of-nanomedicine-journal 